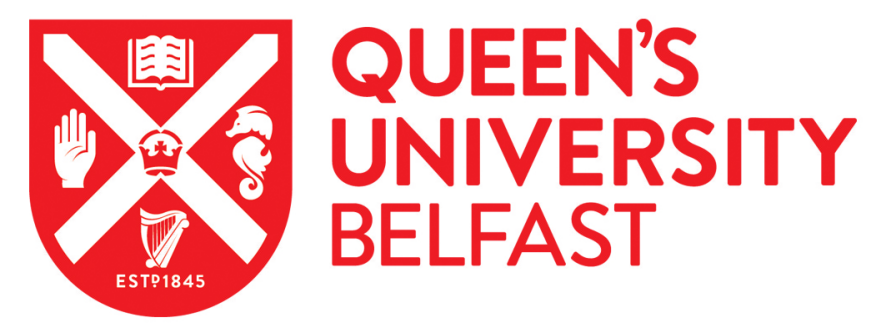

\title{
Diet in Medieval Gaelic Ireland: A Multiproxy Study of the Human Remains from Ballyhanna, Co. Donegal
}

\author{
McKenzie, C., Murphy, E., Guiry, E., Donnelly, C., \& Beglane, F. (2020). Diet in Medieval Gaelic Ireland: A \\ Multiproxy Study of the Human Remains from Ballyhanna, Co. Donegal. Journal of Archaeological Science, 121, \\ [105203]. https://doi.org/10.1016/j.jas.2020.105203
}

Published in:

Journal of Archaeological Science

Document Version:

Peer reviewed version

Queen's University Belfast - Research Portal:

Link to publication record in Queen's University Belfast Research Portal

Publisher rights

(c) 2020 Elsevier Ltd.

This manuscript is distributed under a Creative Commons Attribution-NonCommercial-NoDerivs License

(https://creativecommons.org/licenses/by-nc-nd/4.0/), which permits distribution and reproduction for non-commercial purposes, provided the author and source are cited.

\section{General rights}

Copyright for the publications made accessible via the Queen's University Belfast Research Portal is retained by the author(s) and / or other copyright owners and it is a condition of accessing these publications that users recognise and abide by the legal requirements associated with these rights.

Take down policy

The Research Portal is Queen's institutional repository that provides access to Queen's research output. Every effort has been made to ensure that content in the Research Portal does not infringe any person's rights, or applicable UK laws. If you discover content in the Research Portal that you believe breaches copyright or violates any law, please contact openaccess@qub.ac.uk. 


\title{
Diet in Medieval Gaelic Ireland: A Multiproxy Study of the Human Remains from Ballyhanna, Co. Donegal
}

Catriona J McKenzie ${ }^{1}$, Eileen M Murphy ${ }^{2}$, Eric Guiry ${ }^{3}$, Colm J Donnelly ${ }^{2}$, Fiona Beglane ${ }^{4}$

${ }^{1}$ Department of Archaeology, College of Humanities, University of Exeter, Exeter, EX4 4QE, UK

${ }^{2}$ Archaeology and Palaeoecology, School of Natural and Built Environment, Queen's University Belfast, Belfast, BT7 1NN, Northern Ireland

${ }^{3}$ School of Archaeology and Ancient History, University of Leicester, Mayor's Walk, Leicester, LE1 7RH, United Kingdom; Department of Anthropology, Trent University, Peterborough, ON, K9L0G2, Canada; Department of Anthropology, University of British Columbia, Vancouver, BC, V6T 1Z1, Canada

${ }^{4}$ Centre for Environmental Research Innovation and Sustainability, School of Science, Institute of Technology, Sligo, Ireland

Keywords: dental caries; dental calculus; carbon and nitrogen isotopes; subsistence; economy

\begin{abstract}
This study investigates the nature of diet in a predominantly Late Medieval Gaelic Irish skeletal population and explores whether any sex-based and/or age differences were evident in the population. A smaller sub-sample was also examined to determine whether there was any evidence for dietary change over time between the Early Medieval $(c .700-c .1200)$ and Late Medieval periods (c.1200-c.1600). The dietary evidence was derived using a multiproxy approach that combined information from dental palaeopathology ( $n=356$ adults) and analysis of carbon $\left(\delta^{13} \mathrm{C}\right)$ and nitrogen $\left(\delta^{15} \mathrm{~N}\right)$ stable isotope compositions ( $n=72$ individuals). A higher proportion of females were affected by carious lesions when compared to males. This is possibly suggestive of differing levels of carbohydrate consumption between the sexes, although other factors such as eating habits, and genetic and physiological differences may also have influenced the patterns in the data. The isotopic values indicated that both
\end{abstract}


sexes were consuming similar amounts and types (marine $v s$. terrestrial) of dietary protein. Elevated $\delta^{15} \mathrm{~N}$ indicated breastfeeding among the youngest in society but, once children had been weaned, the dietary protein was isotopically similar across the different age categories. Among a smaller radiocarbon-dated sub-sample $(n=37)$, there was an increase in both the percentage of individuals affected by dental caries and the percentage of teeth affected by dental caries between the Early Medieval and Late Medieval periods. This increase may indicate a greater inclusion of plant-based carbohydrates, such as cereals, in the diet over time, although it may also reflect the younger age distribution of the Early Medieval sample. Interpretations for each of these patterns are discussed with reference to the historical and archaeological evidence. Multiproxy palaeodietary studies for Medieval Ireland are limited and this is the first substantial study of evidence derived from both dental palaeopathology and stable isotope analysis.

\section{Introduction}

Writing in 1584, the Dublin intellectual Richard Stanihurst stated that Ulster was 'almost devoid of the cultivation of man. You will not see many tilled fields there and, as a consequence, the men of Ulster are not great eaters of bread. Among them are many herdsmen but few tillers to break the soil - although it is naturally quite fertile - with the ploughshare' (Barry and Morgan 2013, 105). By arguing that the indigenous population was not fully exploiting the commercial potential of their land, the Anglo-Irish Stanihurst portrayed the Gaelic Irish of the north as uncivilised in comparison to the people living within Dublin and the Pale. This device would become part of an effective argument used in the early seventeenth century in support of British colonisation in Ulster, since it helped to justify the transfer of land to newcomers from England and Scotland (Farrell 2017, 36-38).

In contrast to this view, however, the historical and archaeological evidence suggests that the economy of Late Medieval Gaelic Ireland (c.1200-c.1600) was based upon a mixture of pastoral and arable farming, with dairy, meat and cereal products all incorporated into the diet (Nicholls 2003, 133-137; O’Dowd 1986, 130). It is somewhat unclear, however, whether aquatic sources such as seaweed, shellfish, fish and marine mammals were regularly consumed by the population. The historical sources tend to focus on the upper strata of society, and relatively few contemporary documentary accounts survive which make reference to the diet of the lower classes (for examples see McKenzie and Murphy 2018, 34). 
Indeed, information about the everyday lives of tenant farmers, labourers, clergy, merchants, artisans and the very poor, who would have comprised the majority of the population, are conspicuously absent from the records. Given this paucity of evidence, the human skeletal remains from Ballyhanna (Fig. 1), the largest Gaelic Medieval population to have been excavated from Ireland to date, is of particular importance since it provided an unparalleled opportunity to study the physical remains of these people, who are largely invisible to history (see McKenzie and Murphy 2018). Using data derived from the Ballyhanna population, the overall aim of this study was to reconstruct the long-term dietary composition of the ordinary Late Medieval Irish and to explore whether there were any discernible sex-based and/or agebased differences in diet. This was achieved by incorporating evidence from dental palaeopathology and stable isotope analysis, with the scant historical and archaeological evidence. A secondary aim was to investigate whether there was any evidence for dietary change over time from the Early Medieval to Late Medieval periods. The study also provided an opportunity to ascertain if scientific evidence can provide grounds for the suspicion of political bias in Stanihurst's 1584 statement (Barry and Morgan 2013, 105; Farrell 2017, 36$38)$.

A close link exists between the diet consumed during life and dental health (Lukacs 2012). The type, consistency, and preparation of food will all influence the oral environment and the subsequent development of dental pathologies, particularly dental caries, in an individual (Hillson 2008, 116). Data collected on pathological lesions in the dentition can therefore be used in the reconstruction of past diets (Larsen 2015, 66-86). While a wealth of dental palaeopathological information exists for the Medieval period in Ireland, much of this remains unpublished and it is rarely combined with stable isotope data. Stable carbon $\left(\delta^{13} \mathrm{C}\right)$ and nitrogen $\left(\delta^{15} \mathrm{~N}\right)$ isotope analyses of human and animal tissues can provide direct evidence for dietary practices (for review see Lee-Thorp 2008). This technique has been widely used to reconstruct the diets of human and animal populations from many different time periods and geographical locations, but only a few studies have been undertaken on Irish material and none of these have focused on the Late Medieval period (e.g. Beaumont et al. 2013; Geber 2010; Geber 2011; Guiry et al. 2018a; Knudson et al. 2012; Ryan et al. 2018).

\section{Background}


The townland of Ballyhanna is located on the outskirts of the town of Ballyshannon in southern County Donegal, Ireland, approximately $1 \mathrm{~km}$ from the Atlantic coast. In 2003-2004 a small, single-celled church and graveyard were excavated (NGR 188105, 360834) during a roadwork scheme financed by the National Roads Authority and Donegal County Council. Radiocarbon dates indicate that the graveyard was in use for over a millennium, from the second half of the seventh century into the first quarter of the seventeenth century, although the vast majority of individuals (approximately 86\%; 62/72 of those radiocarbon dated) were laid to rest between the mid- thirteenth and seventeenth centuries (Macdonald and Carver 2015, 56).

By the late twelfth century, Ireland had witnessed the arrival of the Anglo-Normans from England. Their conquest of the country proved to be incomplete, however, and much of the northern province of Ulster - including modern-day County Donegal - remained under Gaelic Irish control. The church at Ballyhanna was a chapel-of-ease that would have served the local community working on an estate owned by the Bishop of Clogher (Crown Commission's Inquisition at Enniskillen on 18 September 1609 cited in Hatchell 1966, 3834; Donnelly 2015, 39). People interred in the graveyard are likely to have been the subtenants of the erenagh, or estate manager, as well as hired labourers who farmed the surrounding church lands (Donnelly 2015, 39). Burials were mostly supine, extended, single interments, aligned west-east, as would be expected for a Christian population (for a detailed discussion of burial practices at Ballyhanna see McKenzie and Murphy 2018).

Small quantities of faunal remains were mixed within the soil of the graveyard including waste from butchery, cooking, craftworking and the remains of non-food species. The assemblage comprised 227 identifiable fragments of bone, derived from cattle, sheep and goat, pig, horse, dog, cat, deer, rabbit and rat, as well as corvid (rook/crow) and pike. Among the domesticated animals, cattle predominated, followed by sheep/goat, and a lesser proportion of pig bones. The isotopic compositions of faunal remains from these graveyard deposits were used to construct a baseline for interpreting human diets, although it does have to be appreciated that the dating of the faunal remains is ambiguous since none were deliberate inclusions within the burials.

\section{Dietary Reconstruction}

\subsection{Historical and archaeological evidence for diet}


Although Late Medieval historical sources are largely silent in relation to the diet of the lower classes in Gaelic Ireland, continuity is presumed throughout the Medieval period, and a richer record of Early Medieval historical sources exist, including law and religious tracts. These suggest that, for the majority, the diet would have comprised bread and milk, supplemented by vegetables, fruit, salted meats, honey, seaweed and salt (Kelly 1997, 316317). Historical documents suggest that oats were the main crop grown and were used to make porridge, gruel, soups, stews, cakes and bread (Nicholls 2003, 133). Other cereals were grown in Gaelic areas - notably barley, rye and wheat - but these tended to be used as rentin-kind payments to the local lord (Ó Doibhlin 1998, 60; O’Dowd 1986, 130). Small amounts of grains would have been processed using quern stones at home, with local mills used for larger quantities (Nicholls 2003, 133). A watermill managed by the erenagh at Ballyhanna would have processed the grain grown locally on the church lands (Donnelly 2015, 40).

Cattle were of particular importance in Gaelic society, as the size and quality of dairy herds were reflective of the wealth and status of a lord (O'Dowd 1986, 130). Milk, primarily from cattle, but also from goats and sheep, would have been used to make products such as cream, cheese, butter, buttermilk, whey, and sour curds, and these would have comprised the main source of dietary protein for the lower classes (Beglane in press; Kelly 1997, 323-330; Nicholls 2003, 137). Since milk production would have peaked between the months of April and September, fresh milk products were consumed predominantly in the summer months, while processed dairy products, such as hard cheeses, would have been kept for the winter (Kelly 1997, 52).

The quantity and quality of meat would have varied depending upon status, with the ruling elites eating the best cuts (Kelly 1997, 358). Meats available would have included beef, mutton, goat and pork and each of the associated species are represented in the small faunal assemblage from Ballyhanna. Most Medieval animal bone assemblages also contain very small numbers of bones from wild animals, such as red deer and wild boar, along with bird and fish (see e.g. Beglane 2012; McCormick and Murray 2007, 39; Murphy 2007). Evidence from historical sources and faunal remains also indicate that poultry (hens and geese) were sometimes kept, for both their eggs and meat (McCormick and Murray 2007, 106).

Cartographic evidence suggests that river fish such as salmon and eels may also have been incorporated into the diet. In a map drawn on 10 October 1593 (British Library Cotton MS Augustus I.ii.38) showing the Battle of the Erne Fords, which took place at Belleek near 
Ballyshannon, the English solider and cartographer John Thomas depicted a large salmon in the River Erne, along with a couple of weirs and the famous salmon 'leape' to the north of Ballyhanna. In the Crown Commission's Inquisition at Lifford in 1609 on church land in County Donegal it was stated that the land of the McGockquin lineage - the erenagh lineage associated with Ballyhanna - included a fishing weir for eels, a watermill, and the 'moytie of a salmon leape called O'Skullion', for all of which they paid an annual rent of three shillings and fourpence to the Bishop of Clogher (Donnelly 2015, 39). For methodological and taphonomic reasons fish bones are rarely recovered from archaeological sites. Sieving was not employed during the excavations at Ballyhanna meaning that the faunal assemblage is biased to larger skeletal elements (O’Connor 2000,31). Recovery of a pike bone from Ballyhanna, however, was suggestive that fish formed at least part of the diet. Two salmon bones were discovered from secure Late Medieval contexts at the excavated tower house (small castle) at Parke's Castle, Co. Leitrim, indicating that salmon was certainly being eaten at this high status Gaelic site (Hamilton-Dyer 2012, 120). Given the riverine nature of Ballyhanna, it seems probable that shellfish may have formed a supplementary component of the diet (see Murray 2007) but only a single scallop shell was recovered during the excavations, and this was considered to have been a pilgrim badge related to the shrine of $\mathrm{St}$ James of Compostela in Spain (McKenzie and Murphy 2018, 45-46).

The Ó Domnaill sept, who were the overlords of much of Donegal during the Late Medieval period, have been described as a maritime lordship, largely dependent upon the fisheries of the coast and the inland rivers for wealth and trade (Mac Eiteagáin 1995, 207; Nicholls 2003, 145). Ports in Donegal traded with ships from England, Scotland, France, and Spain and exports included salmon, herring, eel, and oyster (Mac Eiteagáin 1995, 206). The Ó Domnaill leaders directly facilitated foreign fishing off the west coast of Donegal, taxing the vessels for fishing in their waters (Mac Eiteagáin 1995, 206; Nicholls 2003, 145). Donnelly (2015, 17) notes how a Tudor English official claimed in 1561 that Maghnus Ó Domnaill was the 'best lord of fish in Ireland and he exchangeth fish always with foreign merchants for wine, by which [he] is called in other countries, the king of fish'. Despite the presence of a fishing industry off the west coast, however, it is unclear from the historical sources the extent to which the native diet incorporated marine resources. The suggestion that marine mammals may have been, at the very least occasionally, exploited for meat was supported by archaeological evidence from a Late Medieval animal bone assemblage from Portmuck, Co. Antrim, where butchery marks were identified on two grey seal bones (Murphy 2004, 101). 
Advice provided in Bretha Crólige, an Early Medieval law tract dealing with the maintenance of the sick, notes that invalids suffering from stomach problems should not be supplied with whale-flesh, implying that whale-meat may also have been consumed as and when the opportunity arose (Kelly 1997, 348-349).

\subsection{Dental pathology}

The dental lesions analysed here comprised dental caries and calculus, which previous studies have shown are particularly useful for palaeodietary reconstruction (e.g. Keenleyside 2008). Dental caries are cavities that develop in the crown or root surface of a tooth as a result of demineralisation by organic acids that are produced by oral bacteria during the breakdown of fermentable carbohydrates (Larsen 2015, 67). The aetiology of dental caries is incompletely understood, but factors that influence their development include diet, food texture, speed of food consumption, nutrition, oral and plaque acidity, the nature and flow of saliva, age, genetics, enamel composition, and tooth size and morphology (Hillson 2008; Larsen 2015, 68; Lukacs 2012). A correlation is also evident between the prevalence of dental caries and the amount and frequency of consumption of refined sugars and fermentable carbohydrates in the diet (Hillson 2008, 115-116). A global study by Lukacs (1989, table 7) revealed a general increase, albeit with considerable variability, in the prevalence of carious lesions in teeth from hunter-gatherers (average 1.3\%) to those who practiced a mixed foraging/agriculture economy (average $4.8 \%$ ) to agriculturists (average 10.4\%).

Dental calculus is a mineralised plaque deposit, comprised of a combination of food debris, saliva and bacteria, which attaches to the crown or root of a tooth (Hillson 1996, 254-255). Its aetiology is complex and the precise nature of the relationship between diet and calculus formation is not fully understood. When the frequencies of calculus and caries are compared, however, they can be used to assess the relative levels of proteins versus carbohydrates within the diet of a group. In general terms, diets high in fermentable carbohydrates and low in protein lead to high levels of dental calculus and high levels of dental caries, while diets low in carbohydrates and high in protein result in high levels of dental calculus and low levels of dental caries (Keenleyside 2008).

\subsection{Stable isotope analysis}


The isotopic composition of bone and dentine collagen reflects that of food and drink, particularly protein (Ambrose and Norr, 1993) consumed during life (for review see LeeThorp 2008). In terrestrial environments, human and animal bone collagen $\delta^{13} \mathrm{C}$ reflects the importance of carbon derived from $\mathrm{C}_{3}$ and $\mathrm{C}_{4}$ plants (Vogel and van der Merwe, 1977, DeNiro and Epstein, 1978, Tieszen, 1991) As Ireland has a temperate environment dominated by $\mathrm{C}_{3}$ plants, human $\delta^{13} \mathrm{C}$ values are most useful for distinguishing between the importance of terrestrial (animals and crops) and aquatic (particularly marine fish) foods, which have relatively low and high $\delta^{13} \mathrm{C}$ values, respectively (Chisholm et al. 1982; DeNiro and Epstein 1978). Stable nitrogen isotope compositions can provide information about the relative importance of different kinds of plant and animal proteins in human diet become increasingly elevated (+3-4\%o) with each trophic level step up in a food web (Bocherens and Drucker 2003; Hedges and Reynard 2007; Post 2002; Szpak et al. 2012). For this reason, $\delta^{15} \mathrm{~N}$ values can provide a means of assessing the relative importance of plant versus animal foods (DeNiro and Epstein 1981). Moreover, because aquatic ecosystems can have longer food chains, with more trophic levels than their terrestrial counterparts, diets including uppertrophic level marine or freshwater fish species can be distinguished based on $\delta^{15} \mathrm{~N}$ values (Schoeninger et al. 1983). The isotopic composition of plants and animals at the base of the food web can also vary between time periods, geographical areas, environmental conditions, and cultural practices (Guiry et al. 2018a; Szpak 2014; Van Klinken et al. 2002). Interpretation of human stable isotope data therefore ideally requires associated faunal data to provide a contemporaneous isotopic baseline (Katzenberg 1989).

\section{Materials and Methods}

\subsection{Human Remains}

A total of 1296 skeletons, 869 adults and 427 juveniles, were recorded using standard osteological techniques (McKenzie and Murphy 2018) that conform to professional guidelines (Mitchell and Brickley 2017). Of the adults, 356 had a partial or complete dentition present, $44.6 \%$ (159/356) were from males, $48.9 \%(174 / 356)$ from females and $6.5 \%(23 / 356)$ derived from individuals of indeterminate sex. A total of 6238 teeth were examined. Radiocarbon dating, and $\delta^{13} \mathrm{C}$ and $\delta^{15} \mathrm{~N}$ analyses were undertaken on 72 individuals ( $n=54$ adults; $n=18$ juveniles). The samples were primarily selected to understand the stratigraphy of the graveyard, although a smaller number of individuals were also 
included in the sample as they displayed unusual pathological lesions or traumatic injuries. The radiocarbon-dated sample comprised individuals of both sexes and a range of ages. A smaller sub-sample of 37 adult skeletons had both a radiocarbon date and a dentition present for analysis.

The age-at-death of juveniles was estimated using a combination of epiphyseal fusion data, the diaphyseal lengths of long bones, dental eruption and dental mineralisation (Cunningham et al. 2016; Moorrees et al. 1963; Smith 1991). Biological age estimations were based upon Scheuer and Black (2000, 468-469) and were divided into the following age categories preterm (<37 lunar weeks), full term (37-42 weeks), neonatal (c. 40-44 weeks), infant (1 month to 1 year), younger child (1-6 years), older child (6-12 years) and adolescent (12-18 years). Adult sex determination involved recording sexually dimorphic morphological traits of the skull and pelvis following the recommendations of Ferembach et al. (1980) and Phenice (1969). Adult age estimation was based upon the assessment of late fusing epiphyseal sites throughout the post-cranial skeleton (Cunningham et al. 2016), degeneration of the auricular surface (Lovejoy et al. 1985) and pubic symphysis (Brooks and Suchey 1990), and dental wear (Brothwell 1981). The adult skeletons were divided into three broad age categories - young adults (18-35 years), middle-aged adults (35-50 years) and old adults (50+ years). Adult skeletons that could not be allocated to one of these categories were catalogued as adults ( $>18$ years).

\subsection{Dental palaeopathology}

The assessment of dental palaeopathology in this study focuses solely on prevalence rates of dental caries and calculus in adult dentitions (full details of the dental diseases evident in both adult and juvenile dentitions can be found in McKenzie and Murphy 2018).

The number, location (occlusal, buccal/lingual, interproximal, or root), and approximate size of the carious lesions were recorded for each tooth. Likewise, the amount of dental calculus mild, moderate, or considerable - was also recorded for each tooth (Brothwell 1981, 155). The dental diseases are reported according to both the crude prevalence rate (CPR; the proportion of individuals affected by a dental disease as a proportion of the number of individuals with dentitions present) and true prevalence rate (TPR; the proportion of teeth affected by each disease calculated out of the total number of teeth present). Differences 
between the sexes and age categories were explored using chi-squared tests (Pearson 1900), and statistical significance was defined by probability levels of $p=<0.05$.

\subsection{Stable isotopes}

Of the 72 humans selected for isotopic analyses, samples from 61 individuals originated from bones (primarily rib fragments), while teeth (first molars) were sampled for 11 individuals (Tables 1 and 2). Radiocarbon dates for all humans were measured at the ${ }^{14} \mathrm{CHRONO}$ Centre at Queen's University Belfast (QUB) and calibrated using the CALIB REV 6.0.0 calibration programme and the IntCal09 calibration curve (Reimer et al. 2009). Eleven faunal samples were selected for isotopic analysis and these were derived from ten herbivores (six cattle, three sheep/goat, and one horse) and one omnivore (pig) (Table 3). All of the elements sampled were either fused (adult) bones or, where fusion could not be established, were of essentially adult size, so eliminating the possibility that the results reflect unweaned animals. Additional faunal baseline data were sourced from the literature (for discussion see section 6.2) (Guiry, et al., 2016a, Harrod, et al., 2005, Hutchinson, et al., 2015).

Collagen extractions for humans and animals were performed at the ${ }^{14} \mathrm{CHRONO}$ Centre at QUB and the Archaeology Chemistry Laboratory (ACL) at the University of British Columbia (UBC), respectively, and followed similar procedures based on a modified Longin method (Brown et al. 1988; Bronk Ramsey et al. 2004; Longin 1971). Bone samples were demineralised in hydrochloric acid (HCI; 0.50 M and c. $0.25 \mathrm{M}$ at UBC and QUB, respectively). At UBC, demineralised samples were then treated with $0.1 \mathrm{M}$ sodium hydroxide $(\mathrm{NaOH})$ in an ultrasonic bath (solution refreshed every 15 minutes until the solution remained clear) to remove base-soluble contaminants (Szpak et al. 2017a). Samples were then refluxed in a $10^{-3} \mathrm{M} \mathrm{HCl}$ solution in an oven $\left(56^{\circ} \mathrm{C}\right.$ for $16 \mathrm{hr}$ at QUB; $70^{\circ} \mathrm{C}$ for $48 \mathrm{hr}$ at UBC). Solubilised collagen samples were then purified using $45-90-\mu \mathrm{m}$ mesh filters (Sartorius Group at QUB, Elkay Laboratory Products at UBC) and 30,000 molecular weight cutoff filters (Sartorius Group at QUB, Pall Corporation at UBC), with the $>30 \mathrm{kDa}$ fraction being saved, frozen, and lyophilized for isotopic analyses.

Differing collagen extraction procedures could lead to greater variation in the isotopic composition of resulting collagen extracts if the methods applied differ in the extent to which they: 1) effectively remove humic acid, lipid, and non-collagenous protein contaminants (Szpak, et al., 2017a, Guiry, et al., 2016b, Guiry and Hunt, 2020); and 2) cause selective 
amino acid loss (Collins and Galley, 1998). The main methodological differences between extraction protocols for human and animal bone collagen employed in this study are that $\mathrm{NaOH}$ was not utilised for the human samples, as well as varying demineralization and refluxing conditions. The demineralization and refluxing conditions used in both protocols are within standard guidelines and there is no reason to suspect that these should influence the comparability of results with respect to contamination or selective amino acid loss (Ambrose, 1990; Brown, et al., 1988; Collins and Galley, 1998; Longin, 1971). However, if samples were heavily contaminated with humic acids, it is possible that omission of $\mathrm{NaOH}$ pre-treatment for human collagen extracts could result in slightly lower $\delta^{13} \mathrm{C}$ in human samples relative to animals since humic acids do not contain nitrogen and will have $\delta^{13} \mathrm{C}$ that is lower than collagen. However, any potential effects of humic acid contamination should be mitigated by the use of well-established collagen quality control protocols for screening data, including C: $\mathrm{N}_{\text {Atomic }}$ ratios (2.9 to 3.6) (DeNiro, 1985).

Faunal $\delta^{13} \mathrm{C}$ and $\delta^{15} \mathrm{~N}$ values were measured on $0.5 \mathrm{mg}$ subsamples of bone collagen using an Elementar Vario MICRO cube elemental analyser coupled via continuous flow to an Isoprime isotope ratio mass spectrometer in the ACL at UBC in 2016. Duplicate analyses were performed on all samples. Isotopic measurements were calibrated using a two point calibration curve anchored to United States Geological Survey (USGS) 40 and USGS 41 relative to the Vienna Pee Dee Belemnite (VPDB) for $\delta^{13} \mathrm{C}$ and Ambient Inhalable Reservoir (AIR) for $\delta^{15} \mathrm{~N}$ (Qi et al. 2003). Accuracy of measurements was assessed using internal check standards with the following long-term $\delta$-values: methionine (MET, $\delta^{13} \mathrm{C}-28.62 \pm 0.11 \%$ o and $\delta^{15} \mathrm{~N}-5.03 \pm 0.15 \%$ ), caribou bone collagen (SRM1, $\delta^{13} \mathrm{C}-19.36 \pm 0.11 \%$ and $\delta^{15} \mathrm{~N} 1.81$ $\pm 0.10 \%$ ), and walrus bone collagen (SRM2, $\delta^{13} \mathrm{C}-14.76 \pm 0.12 \%$ and $\delta^{15} \mathrm{~N} 15.59 \pm 0.11 \%$ ). The average absolute difference between measured and known $\delta$-values for all check standards (reproducibility) was $0.01 \%$ for $\delta^{13} \mathrm{C}$ and $0.04 \%$ for $\delta^{15} \mathrm{~N}$. The average difference between duplicate pairs of samples was $0.02 \%$ and $0.01 \%$ for $\delta^{13} \mathrm{C}$ and $\delta^{15} \mathrm{~N}$, respectively. The overall standard uncertainty for samples was \pm 0.16 for both $\delta^{13} \mathrm{C}$ and $\delta^{15} \mathrm{~N}$ (Szpak et al. 2017b).

Human $\delta^{13} \mathrm{C}$ and $\delta^{15} \mathrm{~N}$ values were measured on $1.0 \mathrm{mg}$ subsamples of bone collagen using a Flash elemental analyser coupled via continuous flow to a Thermo Delta V isotope ratio mass spectrometer in the ${ }^{14} \mathrm{CHRONO}$ Centre at QUB in 2009-2010. Duplicate analyses were performed on all samples. Isotopic compositions were calibrated using a single-point calibration anchored to Iso-Analytical (IA)-RO41 (L Alanine using, long-term $\delta^{13} \mathrm{C}=-23.33$ 
$\pm 0.10 \%, \delta^{15} \mathrm{~N}=-5.56 \pm 0.14 \%$ ) (Brooks and Belanger 2005). The standard deviations for IA-RO41 over the course of seven runs was \pm 0.05 for $\delta^{13} \mathrm{C}$ and \pm 0.08 for $\delta^{15} \mathrm{~N}$. The standard deviation for replicate sample analyses $(n=72)$ was \pm 0.02 for $\delta^{13} \mathrm{C}$ and \pm 0.07 for $\delta^{15} \mathrm{~N}$. Although these analyses occurred at a time prior to the adoption of routine two-point calibration and inclusion of check standards in some archaeological stable isotope laboratories (Coplen, et al., 2006, for review see, Szpak, et al., 2017b), an in-house standard with different $\delta$-values (L-Glutamic Acid, long-term $\delta^{13} \mathrm{C}=-37.63 \%$, $\delta^{15} \mathrm{~N}=47.60 \%$ ) was periodically run to ensure that isotopic compositions for samples with lower $\delta^{13} \mathrm{C}$ and higher $\delta^{15} \mathrm{~N}$ were not skewed. Therefore, while acknowledging the possibility of calibration-induced differences in measured isotopic compositions between labs, the human and faunal datasets should be broadly comparable. While, ideally, human and faunal isotopic compositions would have been measured in the same way, it is not always practical to apply current best practices (Szpak, et al., 2017b) to data generated over a decade ago.

Statistical comparisons of isotopic compositions were performed using PAST Vision 3.22 (Hammer, et al., 2001). Normality of distribution was established prior to comparisons of means using Shapiro Wilk tests (Shapiro and Wilk, 1965). Comparisons involving one or more non-normally distributed groups were performed using Mann-Whitney $U$ tests (Mann and Whitney, 1947). Comparisons between two normally distributed groups were performed with a Student's $t$ test (if variances are equal; Student, 1908). Comparisons between more than two normally distributed groups were performed with a One Way ANOVA followed by either a Tukey's post hoc test (if variances are equal; Tukey, 1949) or individual Welch's $t$ tests (if variances are unequal; Welch, 1947). A Levene's test (Levene, 1960) was used to assess homogeneity of variance. A Spearman's $\rho$ test (Spearman, 1907) was used to determine the significance of stable isotope and radiocarbon data.

\section{Results}

\subsection{Dental palaeopathology}

Carious lesions were recorded in 37.6\% (134/356) of adults and, overall, 5.5\% (344/6238) of teeth were affected by the lesions. Females had a higher CPR $(41.4 \% ; 72 / 174)$ than males $(31.4 \% ; 50 / 159)$, although the difference was not statistically significant $\left(\chi^{2}=3.5, \mathrm{df}=1\right.$, $p=0.06$ ) (Fig. 2). A higher proportion of female teeth $(6.8 \% ; 210 / 3098)$ were affected by cavities when compared to male teeth $(4.0 \% ; 109 / 2757)$ (Fig. 3). The number of teeth with 
dental caries in the female dentitions ranged from one to ten (mean $2.9 \pm 2.3$ ), while in males the range was from one to seven (mean $2.2 \pm 1.5$ ). These data indicate that females were more frequently affected by carious lesions than their male counterparts and displayed, on average, a higher number of lesions per affected individual. Dental calculus was almost ubiquitous in the Ballyhanna dentitions with $96.1 \%$ (342/356) of adults, and $90.8 \%$ (5667/6238) of teeth affected. The CPR of dental calculus for males and females was similar with $96.2 \%(153 / 159)$ and $96.0 \%(167 / 174)$ of individuals affected respectively.

A lower proportion of young adults $(26.5 \%$; 48/181) were affected by cavities when compared to middle-aged $(58.1 \% ; 61 / 105)$ and older adults $(52.6 \% ; 10 / 19)$ (see Fig. 2). Some $3.3 \%(123 / 3714)$ of young adult teeth, $8.8 \%$ (165/1865) of teeth from the middle-aged people and 9.1\% (23/254) of older adult teeth were affected (see Fig. 3). Calculus deposits were frequent in all adult age categories, and the CPR for young adults of 96.1\% (174/181), increased to $100.0 \%$ (105/105) for middle-aged adults, and decreased to $89.5 \%(17 / 19)$ for older adults. The decrease in CPR rate among older adults is caused by the inclusion of two older adults with tooth sockets present for analysis, but no surviving teeth due to ante- and post-mortem loss. Although almost every dentition was affected by dental calculus, the majority of deposits tended to range from flecks to slight deposits.

Of the 54 adult skeletons with a radiocarbon date, 37 had dentitions present for analysis. These 37 individuals were separated into two groups, an Early Medieval (c.700-c.1200) sample $(n=9)$ and Late Medieval $(c .1200-c .1600)$ sample $(n=28)$. Even with the small sample sizes, there was an increase in the percentage of individuals affected by carious lesions between the Early Medieval (22.2\%; 2/9) and the Late Medieval period (32.1\%; 9/28), and this was also reflected in the percentage of teeth affected between the Early Medieval sample $(1.3 \% ; 3 / 223)$ and the Late Medieval sample $(2.0 \% ; 11 / 545)$. However, the sample from the Early Medieval period has a higher number of young adults (7/9) when compared to the Late Medieval sample (18/28) and so it is likely that the lower prevalence rate of caries in the Early Medieval sample is reflective of the relatively young age of the sample population.

The CPR of dental calculus was 100\% for both the Early Medieval (9/9) and the Late Medieval (28/28) samples. Overall, the Ballyhanna population is characterised by a low prevalence of dental caries with a high prevalence of minimal deposits of dental calculus. This profile is characteristic of a mixed subsistence economy. 


\subsection{Stable isotopes}

Stable isotope compositions of human samples $(n=72)$ are provided in Tables 1 and 2, while animal $(n=11)$ samples are presented in Table 3. Human $\delta^{13} \mathrm{C}$ values ranged from $-22.1 \%$ to $-19.1 \%$ o (mean $-20.9 \pm 0.5 \%$ ), with $\delta^{15} \mathrm{~N}$ values ranging from $9.4 \%$ to $14.7 \%$ (mean $10.9 \pm$ $0.8 \%$ ). Excluding the five youngest individuals (all three years old or younger at death) who may have been breastfeeding, in the case of infants, or neonates who may potentially have died of nutrition-related complications during pregnancy, the results are as follows $-\delta^{13} \mathrm{C}$ values range from $-22.1 \%$ to $-19.5 \%$ (mean $-20.9 \pm 0.5 \%$ ), and $\delta^{15} \mathrm{~N}$ values range from 9.4\%o to $11.9 \%$ (mean $10.7 \pm 0.5 \%$ ). Some samples were derived from adult teeth and will have isotopic compositions reflecting diet earlier in life, during the time that the tooth was forming. However, there were no statistically significant differences between tooth $(n=11$, mean $\delta^{13} \mathrm{C}-20.7 \pm 0.3 \% ; \delta^{15} \mathrm{~N} 10.8 \pm 0.4 \%$ ) and bone $\left(n=46\right.$, mean $\delta^{13} \mathrm{C}-21.0 \pm 0.4 \%$; $\delta^{15} \mathrm{~N} 10.7 \pm 0.5 \%$ ) datasets for either $\delta^{13} \mathrm{C}$ (Student's $t$ test, $t=1.75, d f=56, p=0.089$; Levene's test, $p=0.736$ ) or $\delta^{15} \mathrm{~N}$ (Student's $t$ test, $t=0.196, d f=56, p=0.845$; Levene's test, $p=0.195$ ) suggesting that childhood and adult diets were similar (Fig. 4). For this reason, data from bones and teeth are combined in subsequent comparisons.

A total of 52 adolescents and adults were of determinable sex, including 17 females and 35 males (see Fig. 4). Female (means $\delta^{13} \mathrm{C}=-20.9 \pm 0.4 \%$, $\delta^{15} \mathrm{~N}=10.8 \pm 0.5 \%$ ) and male (mean $\delta^{13} \mathrm{C}=-20.9 \pm 0.5 \%$ o, $\delta^{15} \mathrm{~N}=10.7 \pm 0.5 \%$ ) isotopic compositions show no statistically significant differences in either $\delta^{13} \mathrm{C}$ (Mann-Whitney $U$ test, $U=290.5, p=0.900$ ) or $\delta^{15} \mathrm{~N}$ (Student's $t$ test, $t=0.320, d f=61, p=0.756$; Levene's test, $p=0.883$ ).

There was also very little isotopic variation evident between age cohorts (Fig. 5). Statistical comparisons between age categories, including children, aged three and older, and adolescents $(n=13)$, young adults $(n=27)$, middle-aged adults $(n=17)$, and old adults $(n=3)$ and adults $(n=7)$, showed no statistically significant age-related differences in $\delta^{13} \mathrm{C}$ (One way ANOVA, $F_{3,63}=1.18, p=0.325$; Levene's test, $p=0.539$ ) or $\delta^{15} \mathrm{~N}$ (One way ANOVA, $F_{3,63}$ $=0.79, p=0.502$; Levene's test, $p=0.760)$. As expected the five youngest individuals (neonates SK 43 and SK 830; infants SK 455, SK 858, and SK 1100) show elevated $\delta^{15} \mathrm{~N}$ values ranging from $11.8 \%$ to $14.7 \%$ (means $\delta^{13} \mathrm{C}=-20.7 \pm 1.0 \%$ o, $\delta^{15} \mathrm{~N}=12.9 \pm 1.1 \%$ ). Human (aged three and older, $n=67$ ) isotopic compositions were compared with mean radiocarbon age (Fig. 6). While no significant correlations were found between ${ }^{14} \mathrm{C}$ (mean of 
$2 \sigma$ calibrated age range) and bone collagen $\delta^{13} \mathrm{C}$ (Spearman's $\rho$ test, $\rho=0.233, p=0.060$ ), a significant correlation was found for $\delta^{15} \mathrm{~N}$ (Spearman's $\rho$ test, $\rho=-0.378, p=0.002$ ). This correlation appears to be driven by higher $\delta^{15} \mathrm{~N}$ for seven samples dating earlier than AD 1000 (means $\delta^{13} \mathrm{C}=-21.1 \pm 0.4 \%$ o, $\delta^{15} \mathrm{~N}=11.4 \pm 0.7 \%$ ). When these individuals are removed ( $n=60$, means $\delta^{13} \mathrm{C}=-20.9 \pm 0.5 \%, \delta^{15} \mathrm{~N}=10.6 \pm 0.5 \%$ ), no significant correlation is observed between radiocarbon dates and $\delta^{15} \mathrm{~N}\left(n=60, p=0.060\right.$; for $\delta^{15} \mathrm{~N}, \rho=-0.054, p=$ $0.681)$.

Relative to humans, domestic livestock $(n=11)$ had lower mean $\delta^{13} \mathrm{C}(-22.6 \pm 0.5 \%)$ and $\delta^{15} \mathrm{~N}\left(6.4 \pm 0.9 \%\right.$ ) values (Fig. 7). The mean $\delta^{13} \mathrm{C}$ and $\delta^{15} \mathrm{~N}$ for cattle $(n=6)$ are $-22.8 \pm 0.6 \%$ and $6.2 \pm 0.7 \%$, respectively, while the corresponding data for sheep $(n=3)$ are $-22.4 \pm 0.5 \%$ and $6.7 \pm 1.0 \%$, respectively. The lone pig sample produced a $\delta^{13} \mathrm{C}$ of $-22.0 \%$ and a $\delta^{15} \mathrm{~N}$ of 7.2\%o. Excluding individuals under the age of three years, the mean human data are approximately $1.7 \%$ less negative for $\delta^{13} \mathrm{C}$ and $4.3 \%$ more positive for $\delta^{15} \mathrm{~N}$ than the domestic animals sampled.

\section{Discussion}

\subsection{Dental palaeopathology}

Overall, there was a true prevalence rate of 5.5\% (344/6238) of teeth affected by dental caries among the Ballyhanna adults. A lower true prevalence rate of $1.3 \%(3 / 223)$ of teeth were affected in the Early Medieval sub-sample increasing to 2.0\% (11/545) in the Late Medieval sub-sample. It is worth highlighting that the phased sub-sample was particularly small and comprised a total of 37 individuals. The overall true prevalence rate is higher than corresponding values previously recorded (3.0\%; 98/3233) across five Early Medieval Irish populations (Novak 2015, 1301), but broadly comparable with data derived from other Medieval skeletal collections, such as those from Early Medieval Ballykilmore 6, Co. Westmeath (4.6\%; Randolph-Quinney 2009), and Late Medieval St Mary of the Isle, Co. Cork $(4.9 \%$; Power 1995, 80). Higher true prevalence rates have been reported for other Irish Medieval population groups, however, including the Early Medieval site of Faughart Lower, Co. Louth (9.0\%; Buckley et al. 2010, 34), and the Late Medieval population from Ardreigh, Co. Kildare (9.6\%; Troy 2010, 23). 
A higher proportion of females than males at Ballyhanna were affected by carious lesions. A similar pattern has been reported in a survey of Early Medieval data from elsewhere in Ireland (see Novak 2015, 1301), as well as at Ballykilmore 6, Co. Westmeath (RandolphQuinney 2009), and at Faughart Lower (Buckley et al. 2010, 34). This trend has also been widely reported in other geographically diverse populations (see Larsen 2015, 73). It is possible that the higher proportion of dental cavities amongst female dentitions is indicative of sex-based dietary differences, with females consuming a greater proportion of carbohydrates and males consuming a greater proportion of animal protein. Alternatively, the trend may be related to differences in consumption patterns with females perhaps eating more frequently throughout the day (Larsen 2015, 75). The aetiology of dental caries is complex, however, and many other genetic and physiological factors related to hormonal differences, salivary flow, and changes in the oral environment during pregnancy could also contribute to this difference (Lukacs and Largaespada 2006; Lukacs 2012). Indeed, reproductive factors may be particularly important given the potentially cumulative effect of the higher number of pregnancies in the past.

Dental calculus was frequently identified in the adult dentitions with an overall TPR of $90.2 \%(3350 / 3714)$ of teeth affected, and an almost equal distribution between males and females. A comparable $100 \%$ of individuals were affected by dental calculus in the radiocarbon dated Early Medieval sub-sample and in the Late Medieval sub-sample. A similarly high TPR of $88.9 \%$ was reported in a survey of Early Medieval Irish collections (Novak 2015, 1301), but a lower proportion $(68.6 \%)$ of adult teeth were affected in the Early Medieval population at Ballykilmore 6 (Randolph-Quinney 2009). The TPR was not reported for Faughart Lower, but deposits were noted in almost 95\% of sexed adults with teeth present for analysis (Buckley et al. 2010, 38). While almost every adult with a dentition at Ballyhanna was affected by dental calculus, the vast majority of deposits were slight.

Overall, the high prevalence of dental calculus and low prevalence of caries in the Ballyhanna population are indicative of a mixed subsistence diet, and reflect a lack of refined sugars and fermentable carbohydrates in the diet. This corroborates the historical evidence that suggests dietary carbohydrates would have come from starch-rich plant foods, such as cereals, particularly oats. If the diet at Ballyhanna had been based predominantly on cereals, however, a higher prevalence of dental caries would be expected. Indeed, the higher true prevalence rates for dental caries reported at Faughart Lower (9.0\%) and Ardreigh (9.6\%), may potentially indicate a greater reliance on cereals. These latter populations were situated 
in the east of the country, in areas where wheat was commonly cultivated and used for bread (Murphy and Potterton 2010,306). Indeed accounts in historical sources, such as the Annals of Ulster for 1497, emphasise this distinction and refer to wheat as the standard crop of the Pale - the area under Anglo-Norman influence - and the oats 'of the Gaels' (Nicholls 2003, 133). Research on the cariogenicity of cereals found that rats fed on wheat were more prone to developing caries compared to those that consumed an oat-based diet (Dodds 1960). As such, it is possible that the lower rate of caries in the Ballyhanna population is due to the consumption of oats, as opposed to wheat. The variation in the main type of cereal grown in different parts of the country may have contributed towards the differences evident in the prevalence of caries observed between Ballyhanna and the other populations.

\subsection{Stable isotopes}

Before interpreting palaeodietary patterns in human bone collagen isotopic compositions, it is important to first consider the suitability of the faunal stable isotope baseline. While it is never possible to know which animals were consumed by humans in the past, palaeodietary analyses should strive to construct isotopic baselines using fauna from the most closely associated spatiotemporal context that is relevant to the human study population. This is important because if faunal isotopic baselines come from a place or time when different proportions of $\mathrm{C}_{3}$ and $\mathrm{C}_{4}$ plants were available, or when factors affecting local nitrogen sources and cycling differed, then resulting interpretations of human $\delta^{13} \mathrm{C}$ and $\delta^{15} \mathrm{~N}$ may be skewed. While Ireland does not have substantial variation in the proportion of $\mathrm{C}_{3}$ and $\mathrm{C}_{4}$ plants (Collins and Jones, 1986), it has undergone large changes in herbivore $\delta^{15} \mathrm{~N}$ through time (Guiry, et al., 2018a), reflecting patterns in prevailing mycorrhizal communities, shifting from ectomycorrhizae- to arbuscular mycorrhizae-dominated, nitrogen cycle openness due to more open land, with increased soil disturbance, and nitrogen inputs (e.g. from stocking or manuring practises; for a review of relevant variables, see Szpak, 2014). This means that, with respect to faunal baseline suitability in Ireland, variation in animal $\delta^{15} \mathrm{~N}$ may require closer attention.

While the faunal baseline used here is constructed from animals from the same graveyard as the humans, and are thus spatially well suited for the analysis, it is not possible to assess when these animals were raised and consumed. For this reason, it is unclear whether they are from exactly the same timeframe as the human population. There are, however, a number of 
circumstantial reasons to anticipate that these faunal data are also temporally suitable. The animals included in the baseline come from several grave fills and therefore they are likely to be representative of foods consumed in the region over a long period of time. Although the animal remains will predate the graves from which they were collected, the $c .1000$ year interment history at this graveyard means that they may still be contemporaneous with some earlier individuals. Recent $\delta^{15} \mathrm{~N}$ evidence from Irish domesticates provides a further line of support. Medieval domesticate $\delta^{15} \mathrm{~N}$ from sites across Ireland ( 15 sites, herbivore $n=100,6.3$ $\pm 1.2 \%$; 15 sites, omnivore $n=79,7.9 \pm 1.9 \%$ (Guiry, et al., 2018a) are close to those observed at Ballyhanna (herbivore $n=10,6.3 \pm 0.8 \%$; omnivore $n=1,7.2 \%$ ) suggesting that these data reflect typical values for the time period. It is also worth bearing in mind that substantial intra-site variability in $\delta^{15} \mathrm{~N}$ (up to $c$. 5\%o) in both herbivores and omnivores is evident across many Irish Medieval sites (Guiry, et al., 2018a), a pattern that is common across historical archaeological sites around the world (Guiry, et al., 2017, Guiry, et al., 2014, Guiry, et al., 2018b, Reitsema, et al., 2015, Guiry, et al., 2012, Guiry, et al., 2015). The extreme degree of isotopic variation in Medieval Irish fauna likely reflects a high level of heterogeneity in both animal husbandry and local nitrogen cycling at relatively small spatial and temporal scales. In this context, even faunal remains that can somehow be directly linked temporally with human populations may not provide a representative baseline for the ebb and flow of isotopic variation in human diets. Given that the Ballyhanna faunal data fits well with others datasets from across Ireland's Medieval period (Guiry, et al., 2018a, Knudson, et al., 2012), it is considered valid for interpreting human diets at Ballyhanna. In doing so, the assumption is that this faunal baseline is not somehow systematically skewed to omit animals with unusually high $\delta^{15} \mathrm{~N}$ due to extreme alterations of local nitrogen cycling and nitrogen inputs, such as due to manuring or the preferential consumption of suckling animals.

Diet at Ballyhanna appears to have been isotopically similar for all individuals, regardless of age or sex, from the age of three years onwards. This lack of variation persists across the entire study period, with $\delta^{13} \mathrm{C}$ showing no change and $\delta^{15} \mathrm{~N}$ showing only a slight, although significant, $-0.8 \%$ shift between the Early and Late Medieval periods (discussed in detail below).

Mean human isotopic compositions are higher for both $\delta^{13} \mathrm{C}$ and $\delta^{15} \mathrm{~N}$ than would be expected for a solely terrestrially based diet, suggesting that aquatic protein may have been consumed. In the context of the faunal isotopic baseline, mean human $\delta^{15} \mathrm{~N}$ values are elevated by $+4.3 \%$ ( $+4.2 \%$ if Early Medieval is excluded $)$ over the mean for domestic animals. If no 
aquatic protein had been included in the diet, then to account for this trophic offset the assumption would be not only a relatively high $\delta^{15} \mathrm{~N}$ trophic enrichment factor (although some have offered more extreme values; O'Connell, et al., 2012 a vast majority of studies estimate this offset at $+3-4 \%$; for reviews, see Hedges and Reynard, 2007, Bocherens and Drucker, 2003, Szpak, et al., 2012, Post, 2002), but also that the people buried at Ballyhanna derived nearly all dietary protein from animal products (either dairy and/or meat). The archaeological and historical evidence suggests this was not the case, however, and that domestic crops, particularly cereals, were an important part of Gaelic diet. In this context, the most parsimonious explanation for higher mean human $\delta^{15} \mathrm{~N}$ values is that they reflect a diet primarily based on terrestrial cereals and vegetables and animal protein in the form of dairy and meat sources, with a supplementary contribution from aquatic protein sources. The relatively large offset between mean $\delta^{13} \mathrm{C}$ values for humans and domestic animals $(+1.7 \%$ o provides further evidence suggestive of a dietary contribution from alternative protein sources with $\delta^{13} \mathrm{C}$ values higher than those in the local terrestrial environment.

Ballyhanna's location on the bank of the River Erne and its close proximity to the Atlantic coastline would have provided access to both freshwater (e.g. eels) and marine (e.g. seaweed, fish and shellfish) resources that could, in turn, contribute a potentially wide range of isotopic values to the local human diet (for review see Guiry 2019). For instance, although Atlantic salmon are born in freshwater environments, they migrate to the ocean before adulthood, later returning to their natal river to spawn, meaning that they have isotopic compositions reflecting a pelagic marine ecosystem. In comparison with terrestrial foods, dietary protein derived from the consumption of anadromous Atlantic salmon (Salmo salar; Guiry et al. 2016a; Medieval period, $n=10$, means $\delta^{13} \mathrm{C}-15.0 \pm 0.5 \%$, $\delta^{15} \mathrm{~N} 11.3 \pm 2.2 \%$ ) would contribute to elevated human $\delta^{13} \mathrm{C}$ and $\delta^{15} \mathrm{~N}$ values. Atlantic cod (Gadus morhua; Hutchinson et al. 2015; Medieval period, $n=17$, means $\delta^{13} \mathrm{C}-12.6 \pm 0.7 \%$, $\delta^{15} \mathrm{~N} 15.2 \pm 0.8 \%$ ), which could have been caught locally, also have high $\delta^{13} \mathrm{C}$ and $\delta^{15} \mathrm{~N}$ values. Given the potentially high costs of cod procurement, in comparison with locally abundant and accessible salmon, as well as the relatively low status of the people interred at Ballyhanna, it seems that a significant dietary contribution from the consumption of cod would be unlikely. Eels are born in a marine environment and then migrate to freshwater lakes and rivers during adulthood, before returning to the sea again to spawn. As such, eels caught during their spawning migrations will have isotopic compositions reflecting a predominantly freshwater environment. Protein derived from catadromous European Eels (Anguilla Anguilla; Harrod et 
al. 2005; modern estuary $n=37$, means $\delta^{13} \mathrm{C}-17.1 \pm 0.3 \%$ [corrected by $+5 \%$ o for muscle collagen offset and $+1.5 \%$ o for Suess effect], $\delta^{15} \mathrm{~N} 12.1 \pm 0.6 \%$ ), which were also locally abundant and collected from the River Erne, would likely contribute to relatively low $\delta^{13} \mathrm{C}$ and high $\delta^{15} \mathrm{~N}$ values for human consumers. Shellfish such as oysters and mussels are yet another potential source of marine-derived protein that has a long history of exploitation in Ireland (Milner and Woodman 2007; Murray 2007; Went 1961). Shellfish middens dating to the Late Medieval period are known from Ireland, such as those at Mannin 4, Co. Galway, and Carrickfin, Co. Donegal, as well as substantial oyster middens, dated on the basis of associated Medieval pottery, in Cork Harbour (McCormick et al. 1996, 82). As marine organisms, shellfish have generally elevated $\delta^{13} \mathrm{C}$ and $\delta^{15} \mathrm{~N}$ values, but modern studies have shown them to have highly variable isotopic values depending on local environmental conditions (for Irish examples see, Jennings and Van Der Molen, 2015; Maloy, et al., 2013) and it is therefore difficult to assess the isotopic effect that local shellfish consumption may have had on Medieval human diet.

Evidence for slightly higher $\delta^{15} \mathrm{~N}$ during the Early Medieval may reflect a greater availability of aquatic resources to earlier populations at Ballyhanna. It is typically assumed that increased consumption of marine resources should result in strong elevation in $\delta^{13} \mathrm{C}$, concomitant with increasing $\delta^{15} \mathrm{~N}$. However, a growing awareness of the complexities of aquatic carbon and nitrogen cycles (for review see, Guiry, 2019) demonstrates that this will not necessarily be the case in all contexts, particularly when pelagic and diadromous species are involved. Baseline data assembled here for aquatic species, for instance, shows that some 'marine' resources such as eels and salmon can have $\delta^{13} \mathrm{C}$ values that are much lower than for example cod. Moreover, as demonstrated by the recovery of a freshwater pike bone from the excavations at Ballyhanna, which can also have a higher $\delta^{15} \mathrm{~N}$ but a much lower $\delta^{13} \mathrm{C}$, it is possible that consumption of other aquatic resources could have contributed to higher human $\delta^{15} \mathrm{~N}$ during the Early Medieval period. However, given the very small difference between results from Earlier and Late Medieval populations $(<1 \%$ ), and the possibility of temporal variation in terrestrial nitrogen baselines in Ireland (Guiry, et al., 2018a), it was not possible to explore this shift in greater detail.

\subsection{Comparison between dental palaeopathology and stable isotopes}


The dietary evidence from both the dental palaeopathology and stable isotope analyses suggests a mixed subsistence diet primarily based on terrestrial plant and animal protein, with a supplementary contribution from aquatic protein sources. Evidence from dental palaeopathology was suggestive that females may have been consuming a greater proportion of fermentable carbohydrates than their male counterparts, although it seems highly probable that the difference in the prevalence of dental caries between the sexes could also be due to genetic and physiological differences, hormones, multiple pregnancies and perhaps eating patterns. Human bone collagen isotopic compositions, which are more strongly influenced by dietary protein intake (Ambrose and Norr, 1993), showed no differences between male and female diets. These two lines of evidence are complementary rather than contradictory, with the dental palaeopathology informing about the levels of fermentable carbohydrates in the diet and the isotopic composition of bone collagen providing information on the dietary protein intake. In this context, the differing but complementary observations offered by each approach provide a valuable example of the potential of combining multiple lines of evidence. They also serve as a cautionary tale for the kinds of interpretations that may be missed when a single technique is used.

\subsection{Isotopic evidence for childhood}

Caution is required when interpreting the isotopic composition of collagen from young children because their bone collagen represents a relatively short-term dietary average and may therefore be more strongly affected by seasonal variation or anomalous situations, and their premature deaths could be related to atypical nutritional stresses (Beaumont, et al., 2018). Elevated $\delta^{15} \mathrm{~N}$ values among the very youngest members of the Ballyhanna population provide evidence for nutritional processes influencing mothers and/or neonatal babies as well as infants. As neonates should have isotopic compositions similar to their mothers, the high $\delta^{15} \mathrm{~N}$ of two neonate individuals included in this study, SK 43 and SK 830, may indicate that their mothers' were undergoing nutritional stress (which can cause similar isotopic shifts, e.g., Hobson, et al., 1993) or had otherwise unusual diets. High $\delta^{15} \mathrm{~N}$ in one infant (SK 1100) and two younger children (SK 455, SK 858), followed by lower values in slightly older children (SK 121, SK 528, SK 1029) suggest that babies and young children were breastfed until approximately 1-3 years of age after which children aged 3-12 years began eating an isotopically similar diet to adolescents and adults. 


\section{Conclusion}

This paper has presented an investigation into the nature of diet within Medieval Gaelic Ireland through an assessment of dental palaeopathology and stable isotope compositions from the skeletal population excavated from a graveyard at Ballyhanna, Co. Donegal, in the northern province of Ulster. The start of the article highlighted Richard Stanihurst's statement of 1584 that inferred the people of Ulster did not cultivate the naturally fertile land (Barry and Morgan 2013, 105). This was then used as a political device to help justify the British colonisation of Ulster in the early seventeenth century - the native people did not use the land so it could legitimately be transferred to newcomers from England and Scotland (Farrell 2017, 36-38).

Stanihurst's view, however, is contradicted by the evidence in Medieval Gaelic historical sources which highlight that animal proteins were indeed an important component of the Gaelic Irish diet, but that so too were cereals, particularly oats, which were used in the production of porridge and oatcakes (Nicholls 2003, 133). The results obtained in the current study now provide scientific evidence that support these historical sources. The Gaelic Irish engaged in both pastoral and arable farming and they consumed a mixed diet comprised of cereals and animal products. The consumption of oats by the people buried at Ballyhanna may be responsible for the lower level of caries evident in their dentitions compared to those of comparator populations who lived in the east of the island in areas of Anglo-Norman influence where wheat would have been the predominant cereal crop (see Dodds 1960; Nicholls 2003, 133).

A further finding of interest is the determination that the mean human isotopic compositions are higher for both $\delta^{13} \mathrm{C}$ and $\delta^{15} \mathrm{~N}$ than would be expected for a solely terrestrially based diet, thereby suggesting that aquatic protein may have been consumed. Given Ballyhanna's location on the River Erne and close proximity to the Erne estuary it might appear unsurprising that the local population were incorporating aquatic foods in their diet, and the isotopic evidence now suggests that fish and sea products were indeed part of the Gaelic diet. Fish were important to the economy of the local Ó Domnaill lordship and it is documented that foreign fishermen brought them wine in return for fishing rights (Donnelly 2015, 28; Mac Eiteagáin 1995, 207). While it has been surmised that local people may have provided help to the foreign crews by processing their catches on shore, there was no definitive 
evidence that the population were consuming aquatic foods. The results from the current study, however, now suggest that they were, either by way of fish received in payment for their assistance to the foreign fishermen, or through the marine foods gathered and caught by their own endeavours along the seashore and the River Erne.

The isotopic results also suggest no significant difference in the protein composition of the diet of adult males and females, however a difference in the prevalence of carious lesions was recorded between males and females. Given the widespread trend in different temporal and geographical populations of females having a higher prevalence of caries it seems probable that physiological reproductive factors may be influencing this pattern (Lukacs and Largaespada 2006). Once children were weaned onto solid foods, there seems to have been little variation in diet, with most children and adults consuming a diet that was comprised of cereals, animal products, and some aquatic protein sources. To conclude, results obtained through the current study have consolidated our understanding of diet in Medieval Gaelic Ireland by confirming the evidence from the contemporary Gaelic historical sources and refuting those of a colonial nature. New insights have also been gained into the use of aquatic foodstuffs. The study has highlighted the importance of employing a multi-proxy approach in palaeodietary reconstructions to enable a more nuanced and complete interpretation of past diet.

\section{Acknowledgements}

This work was undertaken as part of the Ballyhanna Research Project (BPR), which was funded by the then National Roads Authority, now Transport Infrastructure Ireland, through Donegal County Council. We are particularly grateful to Michael McDonagh, National Monuments Service, Department of Culture, Heritage and the Gaeltacht, for leading the BPR project and for his unwavering support. We also thank Dr Nessa O'Connor, National Museums Ireland, for facilitating acquisition of the necessary licences to undertake the analysis. We are grateful to Prof. Michael P. Richards, Simon Fraser University, for providing access to facilities and for commenting on an earlier draft of this article. We also thank Prof. Naomi Skyes and Dr Alex Pryor, University of Exeter, for their advice regarding the interpretation of stable isotope data. We are very grateful to Libby Mulqueeny, Queen's University Belfast, for producing Figure 1. We also acknowledge the support of the Centre for Environmental Research Innovation and Sustainability at the Institute of Technology, Sligo. We very much appreciate the helpful comments provided by the anonymous reviewers. 


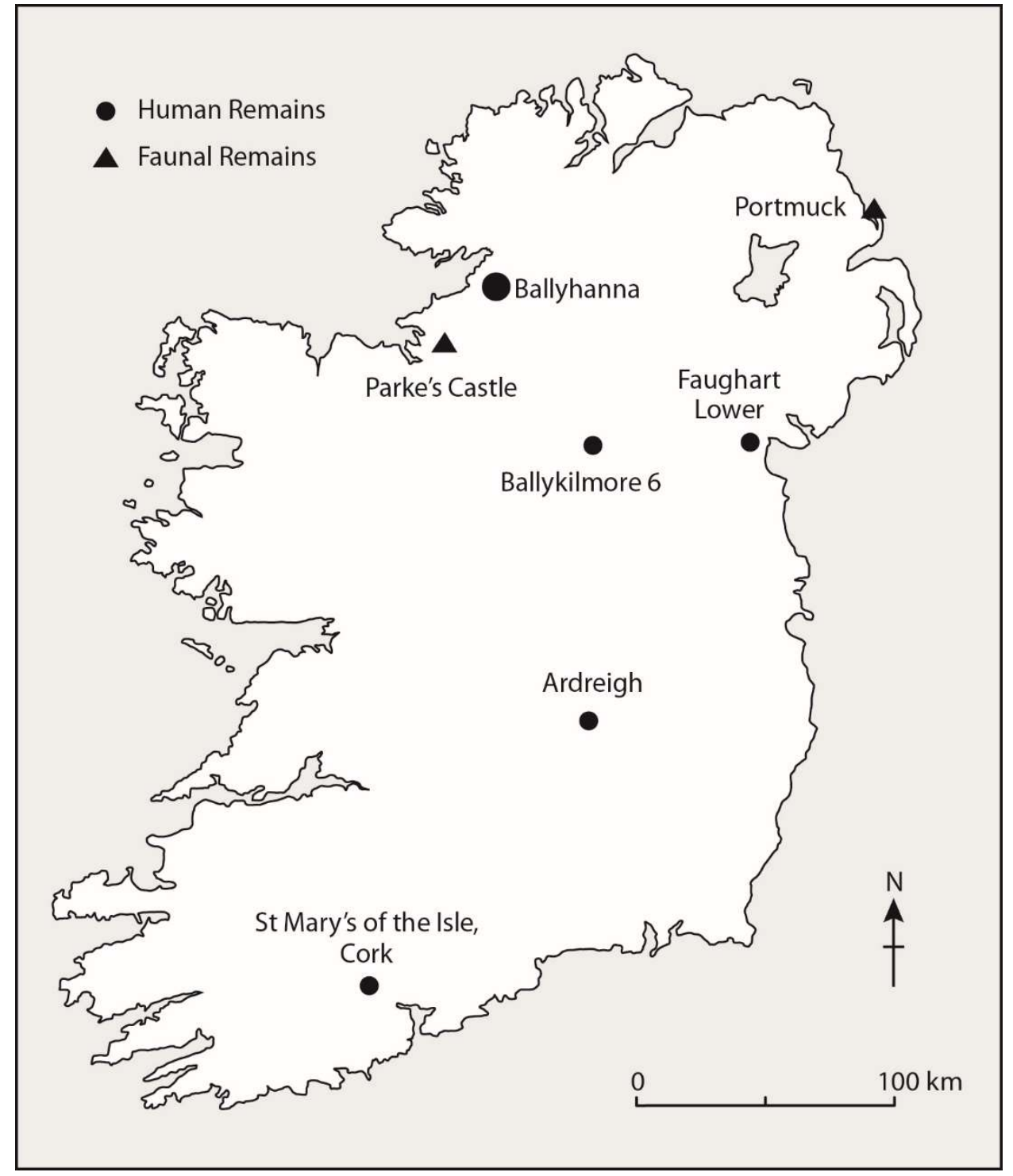

Fig. 1: Location map of Ireland showing the sites mentioned in the text. Human and faunal remains from Ballyhanna were included in the analysis, with human and faunal remains from a range of other sites across the island used for additional information or for comparative purposes. 


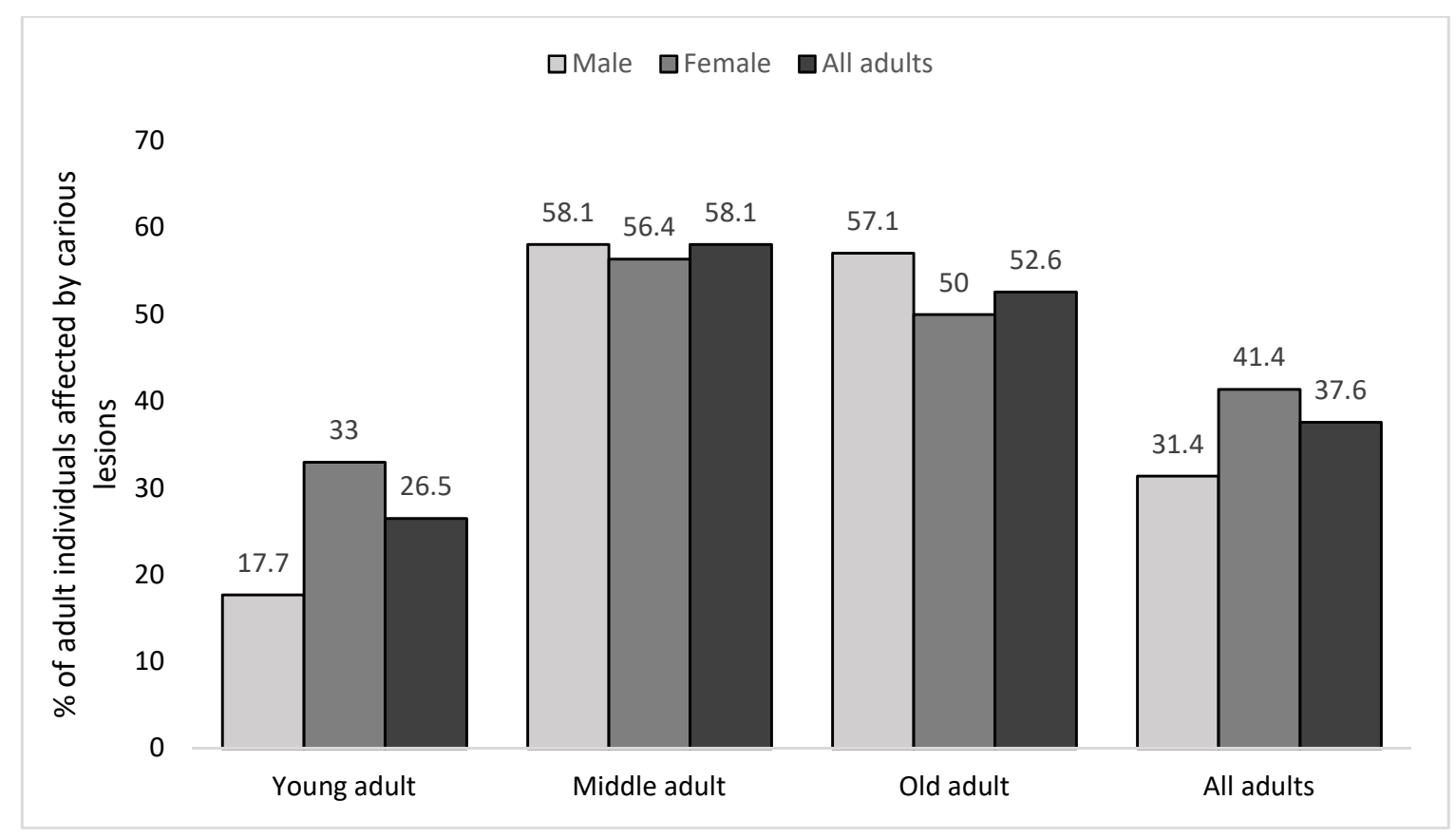

Fig. 2: Percentage of individuals affected by carious lesions by age and sex ( $n=134 / 356)$.

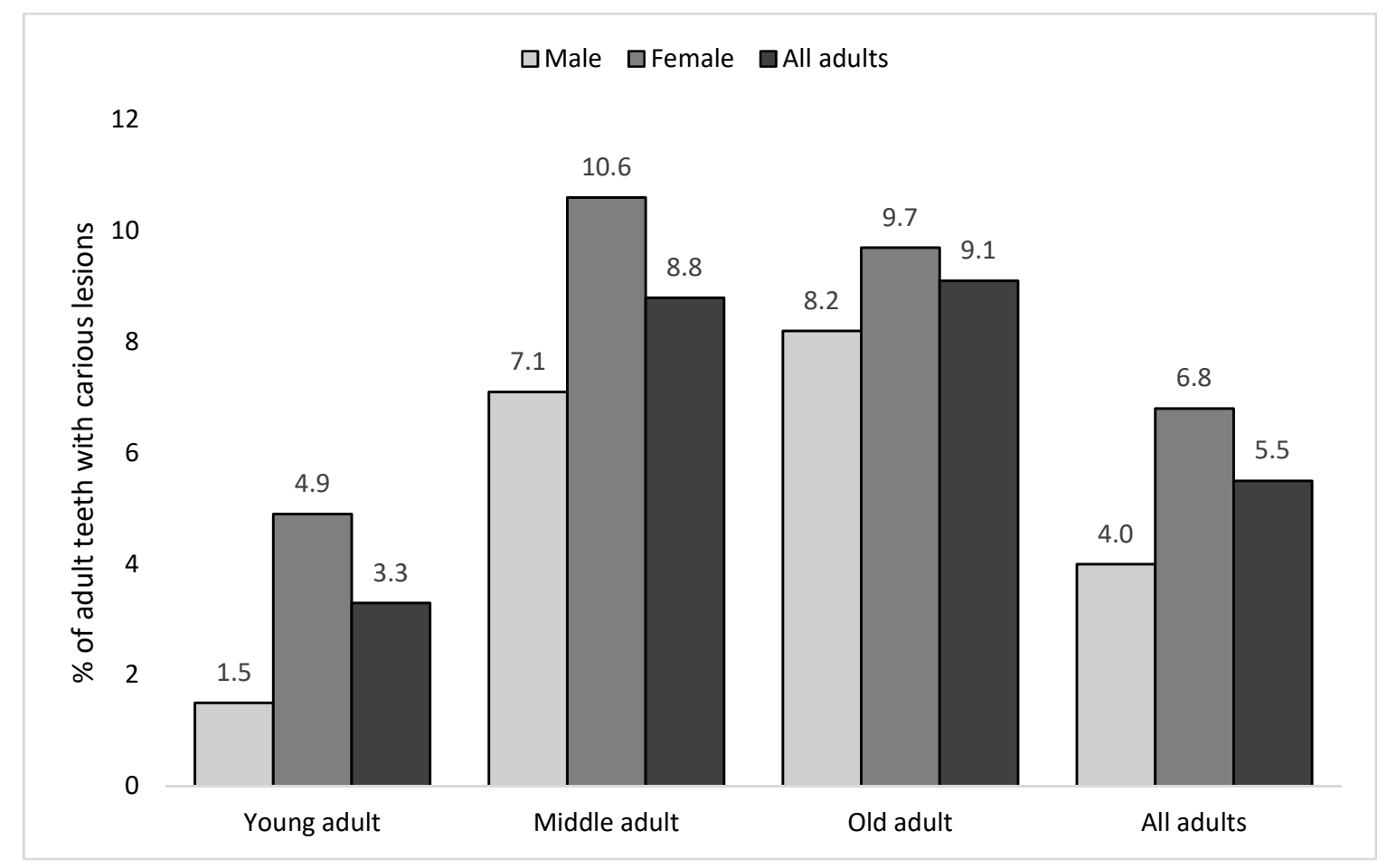

Fig. 3: Percentage of teeth with carious lesions by age and sex $(n=344 / 6238)$. 


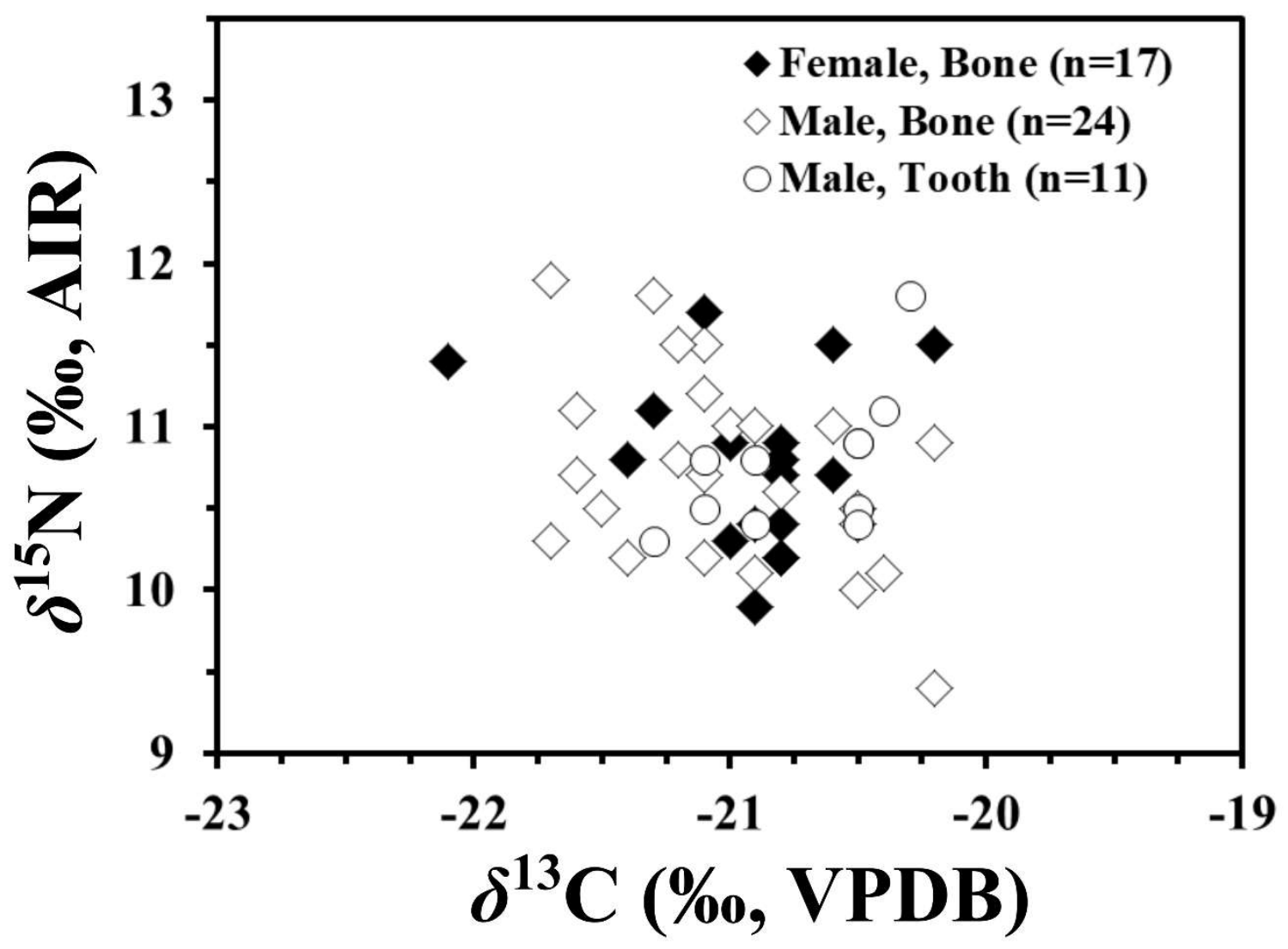

Fig. 4: Plot of $\delta^{13} \mathrm{C}$ and $\delta^{15} \mathrm{~N}$ for human adults differentiated by sex and sample materia 


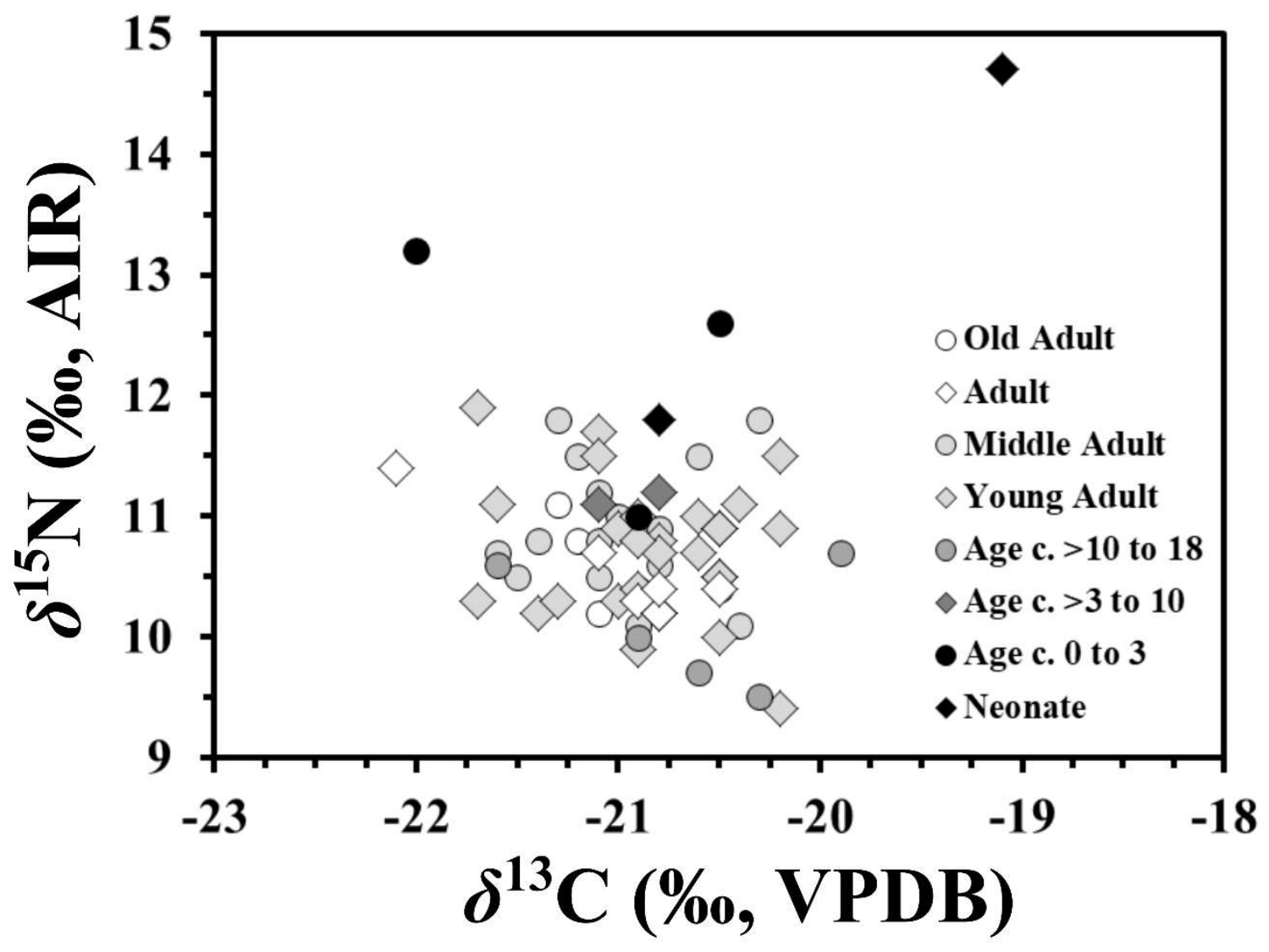

Fig. 5: Plot of $\delta^{13} \mathrm{C}$ and $\delta^{15} \mathrm{~N}$ for all humans differentiated by age group. 


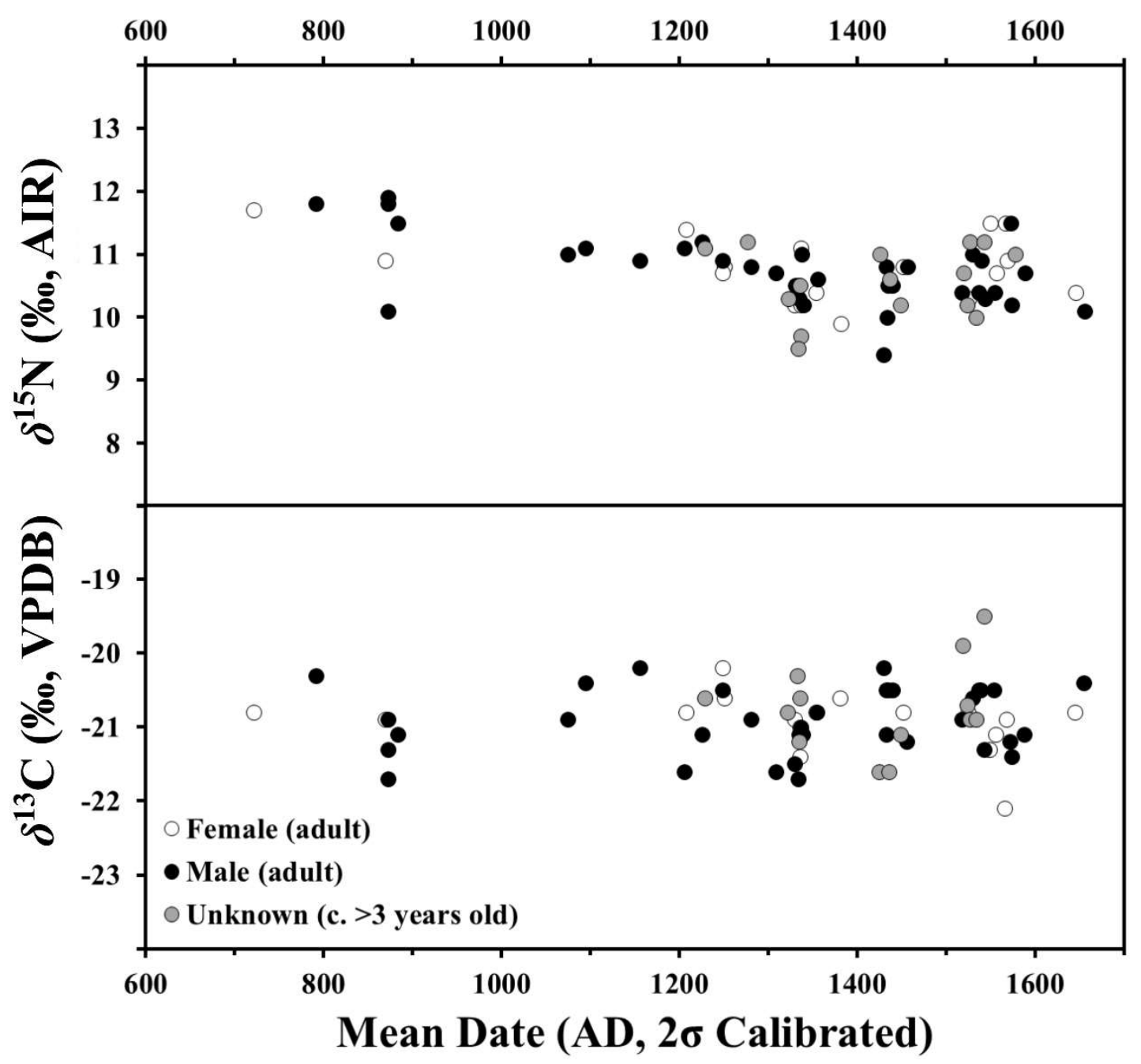

Fig. 6: Plot of $\delta^{13} \mathrm{C}$ and $\delta^{15} \mathrm{~N}$ versus time for humans. 


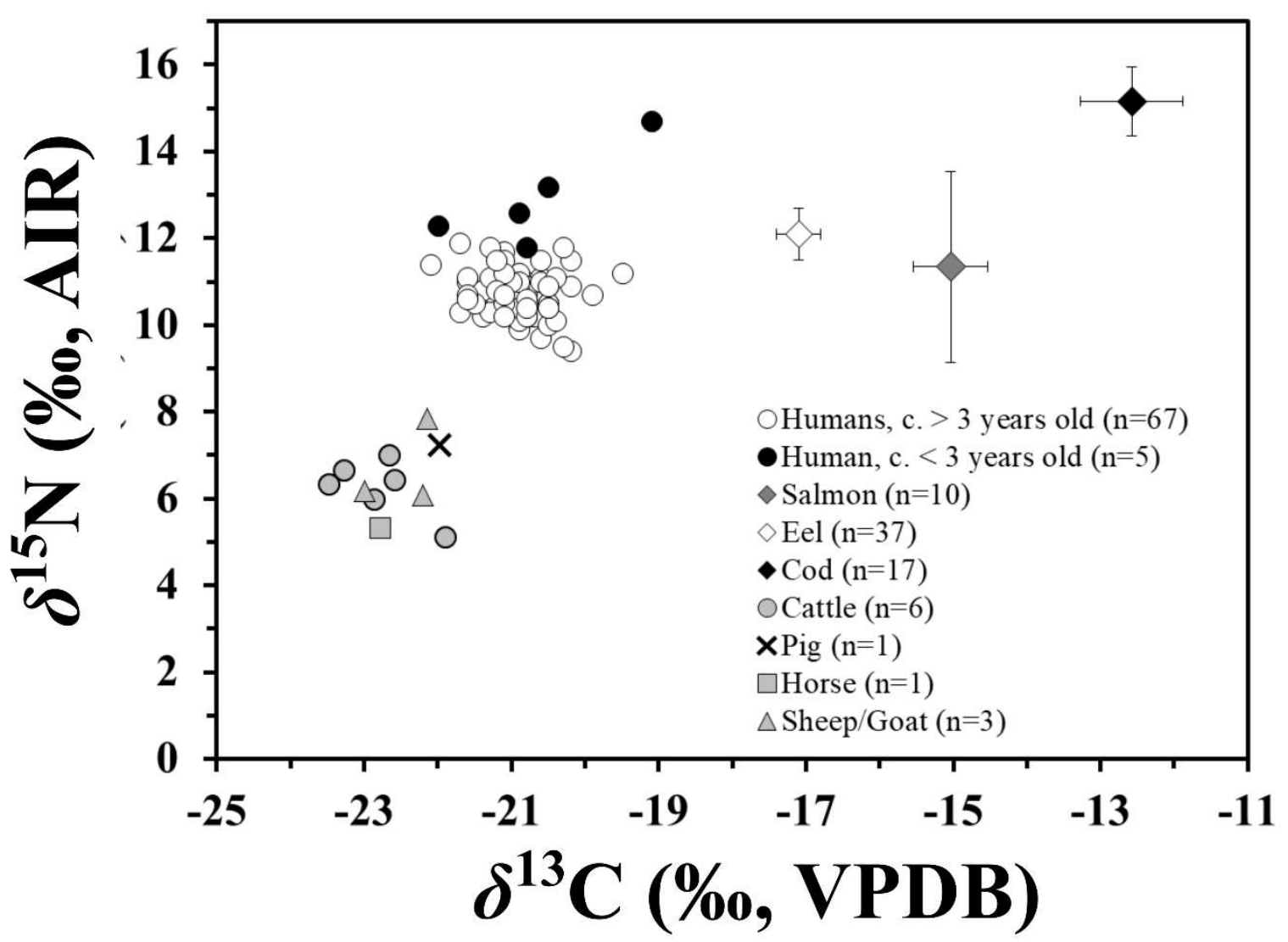

Fig. 7: $\delta^{13} \mathrm{C}$ and $\delta^{15} \mathrm{~N}$ for humans showing faunal baseline. Fish data are from (Guiry, et al., 2016a, Harrod, et al., 2005, Hutchinson, et al., 2015). 
Table 1: Details of the adults from Ballyhanna included in the study.

\begin{tabular}{|c|c|c|c|c|c|c|c|c|c|c|}
\hline Context & $\begin{array}{c}\text { UB } \\
\text { Number } \\
\end{array}$ & $\begin{array}{c}\text { Calibrated } \\
\text { date }\end{array}$ & $\begin{array}{c}\text { Calibrated } \\
\text { date }\end{array}$ & $\begin{array}{l}\text { Skeletal } \\
\text { element }\end{array}$ & Sex & Age & $\delta^{13} \mathbf{C}$ & $\delta^{15} \mathrm{~N}$ & Collagen & $\mathrm{C}: \mathrm{N}$ \\
\hline & & 1 sigma & 2 sigma & sampled & & & & & yield \% & \\
\hline SK 24 & 14974 & $\begin{array}{l}\text { AD 1439- } \\
1451\end{array}$ & $\begin{array}{l}\text { AD 1432- } \\
1465\end{array}$ & Tibia & - & Adult & 20.8 & 10.2 & 5.9 & 3.3 \\
\hline SK 787 & 14972 & $\begin{array}{l}\text { AD 1273- } \\
1290\end{array}$ & $\begin{array}{l}\text { AD 1263- } \\
1381\end{array}$ & Vertebra & - & Adult & $\begin{array}{c}- \\
20.9 \\
\end{array}$ & 10.3 & 0.8 & 3.3 \\
\hline SK 70 & 14985 & $\begin{array}{l}\text { AD 1285- } \\
1386\end{array}$ & $\begin{array}{l}\text { AD 1277- } \\
1395\end{array}$ & Rib & Female & $\begin{array}{l}\text { Young } \\
\text { Adult }\end{array}$ & $\begin{array}{c}- \\
20.8 \\
\end{array}$ & 10.2 & 20.3 & 3.2 \\
\hline SK 153 & 14975 & $\begin{array}{l}\text { AD 1228- } \\
1271\end{array}$ & $\begin{array}{l}\text { AD 1223- } \\
1274\end{array}$ & Rib & Female & $\begin{array}{l}\text { Young } \\
\text { Adult }\end{array}$ & $\begin{array}{c}- \\
20.8 \\
\end{array}$ & 10.7 & 5.7 & 3.3 \\
\hline SK 182 & 11441 & $\begin{array}{l}\text { AD 1494- } \\
1631\end{array}$ & $\begin{array}{l}\text { AD 1477- } \\
1635\end{array}$ & Rib & Female & $\begin{array}{l}\text { Young } \\
\text { Adult }\end{array}$ & $\begin{array}{c}- \\
20.6\end{array}$ & 10.7 & 14.8 & 3.1 \\
\hline SK 477 & 14979 & $\begin{array}{l}\text { AD 1441- } \\
1486\end{array}$ & $\begin{array}{l}\text { AD 1430- } \\
1620\end{array}$ & Rib & Female & $\begin{array}{l}\text { Young } \\
\text { Adult }\end{array}$ & $\begin{array}{c}- \\
21.0\end{array}$ & 10.3 & 3.0 & 3.2 \\
\hline SK 670 & 11446 & $\begin{array}{l}\text { AD 1402- } \\
1430\end{array}$ & $\begin{array}{l}\text { AD 1324- } \\
1438\end{array}$ & Rib & Female & $\begin{array}{l}\text { Young } \\
\text { Adult }\end{array}$ & $\begin{array}{c}- \\
20.9\end{array}$ & 9.9 & 26.3 & 3.2 \\
\hline SK 857 & 11447 & $\begin{array}{l}\text { AD 782- } \\
936\end{array}$ & $\begin{array}{l}\text { AD 778- } \\
961\end{array}$ & Rib & Female & $\begin{array}{l}\text { Young } \\
\text { Adult }\end{array}$ & - & 10.9 & 17.1 & 3.2 \\
\hline $\begin{array}{l}\text { SK } \\
1009 \\
\end{array}$ & 14988 & $\begin{array}{l}\text { AD 1435- } \\
1455\end{array}$ & $\begin{array}{l}\text { AD 1425- } \\
1478\end{array}$ & Rib & Female & $\begin{array}{l}\text { Young } \\
\text { Adult }\end{array}$ & $\begin{array}{c}- \\
20.8 \\
\end{array}$ & 10.8 & 4.7 & 3.3 \\
\hline $\begin{array}{l}\text { SK } \\
1201 \mathrm{~A}\end{array}$ & 11451 & $\begin{array}{l}\text { AD 1484- } \\
1631\end{array}$ & $\begin{array}{l}\text { AD 1460- } \\
1638\end{array}$ & Rib & Female & $\begin{array}{l}\text { Young } \\
\text { Adult }\end{array}$ & $\begin{array}{c}- \\
20.2\end{array}$ & 11.5 & 23.0 & 3.4 \\
\hline $\begin{array}{l}\text { SK } \\
1242 \\
\end{array}$ & 11453 & $\begin{array}{l}\text { AD 679- } \\
767\end{array}$ & $\begin{array}{l}\text { AD 670- } \\
772\end{array}$ & Rib & Female & $\begin{array}{l}\text { Young } \\
\text { Adult }\end{array}$ & $\begin{array}{c}- \\
21.1 \\
\end{array}$ & 11.7 & 25.0 & 3.5 \\
\hline SK 407 & 14981 & $\begin{array}{l}\text { AD 1519- } \\
1635\end{array}$ & $\begin{array}{l}\text { AD 1489- } \\
1643\end{array}$ & Rib & Female & $\begin{array}{l}\text { Middle } \\
\text { Adult }\end{array}$ & $\begin{array}{c}- \\
20.6\end{array}$ & 11.5 & 4.8 & 3.2 \\
\hline SK 495 & 14990 & $\begin{array}{l}\text { AD 1524- } \\
1654\end{array}$ & $\begin{array}{l}\text { AD 1499- } \\
1791\end{array}$ & Rib & Female & $\begin{array}{l}\text { Middle } \\
\text { Adult }\end{array}$ & $\begin{array}{c}- \\
20.9\end{array}$ & 10.4 & 4.1 & 3.3 \\
\hline SK 543 & 14995 & $\begin{array}{l}\text { AD 1244- } \\
1276\end{array}$ & $\begin{array}{l}\text { AD 1225- } \\
1276\end{array}$ & Rib & Female & $\begin{array}{l}\text { Middle } \\
\text { Adult }\end{array}$ & $\begin{array}{c}- \\
21.4 \\
\end{array}$ & 10.8 & 3.6 & 3.3 \\
\hline SK 882 & 11448 & $\begin{array}{l}\text { AD 1521- } \\
1642\end{array}$ & $\begin{array}{l}\text { AD 1488- } \\
1648\end{array}$ & Rib & Female & $\begin{array}{l}\text { Middle } \\
\text { Adult }\end{array}$ & $\begin{array}{c}- \\
20.8\end{array}$ & 10.9 & 17.6 & 3.4 \\
\hline SK 111 & 14977 & $\begin{array}{l}\text { AD 1290- } \\
1383\end{array}$ & $\begin{array}{l}\text { AD 1284- } \\
1388\end{array}$ & Rib & Female & $\begin{array}{l}\text { Old } \\
\text { Adult }\end{array}$ & 21.3 & 11.1 & 6.7 & 3.2 \\
\hline SK 432 & 14982 & $\begin{array}{l}\text { AD 1173- } \\
1220\end{array}$ & $\begin{array}{l}\text { AD 1160- } \\
1254\end{array}$ & Rib & Female & Adult & $\begin{array}{c}- \\
22.1 \\
\end{array}$ & 11.4 & 1.4 & 3.3 \\
\hline SK 680 & 15156 & $\begin{array}{l}\text { AD 1312- } \\
1397\end{array}$ & $\begin{array}{l}\text { AD 1302- } \\
1405\end{array}$ & Scapula & Female & Adult & $\begin{array}{c}- \\
20.8\end{array}$ & 10.4 & 5.9 & 3.3 \\
\hline $\begin{array}{l}\text { SK } \\
1135 \\
\end{array}$ & 14987 & $\begin{array}{l}\text { AD 1279- } \\
1378\end{array}$ & $\begin{array}{l}\text { AD 1273- } \\
1386\end{array}$ & Femur & Female & Adult & $\begin{array}{c}- \\
20.8\end{array}$ & 10.2 & 5.6 & 3.3 \\
\hline & & & & & $\begin{array}{c}\text { Female } \\
\text { mean }\end{array}$ & & $\begin{array}{c}- \\
20.9 \\
\end{array}$ & 10.8 & & \\
\hline SK 30 & 11440 & $\begin{array}{l}\text { AD 1427- } \\
1444\end{array}$ & $\begin{array}{l}\text { AD 1415- } \\
1451\end{array}$ & Rib & Male & $\begin{array}{l}\text { Young } \\
\text { Adult }\end{array}$ & $\begin{array}{c}- \\
20.5\end{array}$ & 10.0 & 17.9 & 3.4 \\
\hline SK 86 & 15981 & $\begin{array}{l}\text { AD 1421- } \\
1447\end{array}$ & $\begin{array}{l}\text { AD 1403- } \\
1476\end{array}$ & M1 tooth & Male & $\begin{array}{l}\text { Young } \\
\text { Adult }\end{array}$ & $\begin{array}{c}- \\
20.5 \\
\end{array}$ & 10.5 & 7.6 & 3.2 \\
\hline $\begin{array}{l}\text { SK } \\
102 \mathrm{~A}\end{array}$ & 14978 & $\begin{array}{l}\text { AD 1430- } \\
1444\end{array}$ & $\begin{array}{l}\text { AD 1420- } \\
1449\end{array}$ & Rib & Male & $\begin{array}{l}\text { Young } \\
\text { Adult }\end{array}$ & 20.5 & 10.5 & 4.3 & 3.2 \\
\hline SK 295 & 15973 & $\begin{array}{l}\text { AD 1227- } \\
1273\end{array}$ & $\begin{array}{l}\text { AD 1220- } \\
1277\end{array}$ & I2 tooth & Male & $\begin{array}{l}\text { Young } \\
\text { Adult }\end{array}$ & $\begin{array}{c}- \\
20.5 \\
\end{array}$ & 10.9 & 3.4 & 3.3 \\
\hline SK 331 & 11443 & $\begin{array}{l}\text { AD 1169- } \\
1215\end{array}$ & $\begin{array}{l}\text { AD 1057- } \\
1254\end{array}$ & Rib & Male & $\begin{array}{l}\text { Young } \\
\text { Adult }\end{array}$ & $\begin{array}{c}- \\
20.2\end{array}$ & 10.9 & 4.3 & 3.2 \\
\hline SK 484 & 15982 & $\begin{array}{l}\text { AD 1226- } \\
1281\end{array}$ & $\begin{array}{l}\text { AD 1182- } \\
1379\end{array}$ & M3 tooth & Male & $\begin{array}{l}\text { Young } \\
\text { Adult }\end{array}$ & $\begin{array}{c}- \\
20.9\end{array}$ & 10.8 & 4.1 & 3.3 \\
\hline SK 555 & 14971 & $\begin{array}{l}\text { AD 1017- } \\
1151\end{array}$ & $\begin{array}{l}\text { AD 994- } \\
1155\end{array}$ & Rib & Male & $\begin{array}{l}\text { Young } \\
\text { Adult }\end{array}$ & $\begin{array}{c}- \\
20.9 \\
\end{array}$ & 11.0 & 0.8 & 3.4 \\
\hline SK 566 & 11445 & $\begin{array}{l}\text { AD 783- } \\
942\end{array}$ & $\begin{array}{l}\text { AD 779- } \\
966\end{array}$ & Rib & Male & $\begin{array}{l}\text { Young } \\
\text { Adult }\end{array}$ & $\begin{array}{c}- \\
21.7 \\
\end{array}$ & 11.9 & 3.2 & 3.2 \\
\hline SK 571 & 15975 & $\begin{array}{l}\text { AD 1040- } \\
1154\end{array}$ & $\begin{array}{l}\text { AD 1028- } \\
1161\end{array}$ & M3 tooth & Male & $\begin{array}{l}\text { Young } \\
\text { Adult }\end{array}$ & $\begin{array}{c}- \\
20.4 \\
\end{array}$ & 11.1 & 2.5 & 3.3 \\
\hline
\end{tabular}




\begin{tabular}{|c|c|c|c|c|c|c|c|c|c|c|}
\hline SK 824 & 14992 & $\begin{array}{l}\text { AD 1422- } \\
1442\end{array}$ & $\begin{array}{l}\text { AD 1409- } \\
1450\end{array}$ & Rib & Male & $\begin{array}{l}\text { Young } \\
\text { Adult }\end{array}$ & 20.2 & 9.4 & 4.0 & 3.3 \\
\hline SK 850 & 15976 & $\begin{array}{l}\text { AD 1469- } \\
1619\end{array}$ & $\begin{array}{l}\text { AD 1455- } \\
1631\end{array}$ & $\begin{array}{l}\text { M1 \& M2 } \\
\text { teeth }\end{array}$ & Male & $\begin{array}{l}\text { Young } \\
\text { Adult }\end{array}$ & - & 10.3 & 2.7 & 3.3 \\
\hline SK 927 & 15977 & $\begin{array}{l}\text { AD 1438- } \\
1462\end{array}$ & $\begin{array}{l}\text { AD 1429- } \\
1606\end{array}$ & M1 tooth & Male & $\begin{array}{l}\text { Young } \\
\text { Adult }\end{array}$ & $\begin{array}{c}- \\
20.9\end{array}$ & 10.4 & 6.4 & 3.2 \\
\hline SK 982 & 15983 & $\begin{array}{l}\text { AD 1522- } \\
1647\end{array}$ & $\begin{array}{l}\text { AD 1494- } \\
1653\end{array}$ & Rib & Male & $\begin{array}{l}\text { Young } \\
\text { Adult }\end{array}$ & $\begin{array}{c}- \\
21.4\end{array}$ & 10.2 & 23.8 & 3.3 \\
\hline $\begin{array}{l}\text { SK } \\
1113\end{array}$ & 15984 & $\begin{array}{l}\text { AD 1286- } \\
1382\end{array}$ & $\begin{array}{l}\text { AD 1280- } \\
1388\end{array}$ & Rib & Male & $\begin{array}{l}\text { Young } \\
\text { Adult }\end{array}$ & $\begin{array}{c}- \\
21.7\end{array}$ & 10.3 & 7.1 & 3.6 \\
\hline $\begin{array}{l}\text { SK } \\
1134\end{array}$ & 14983 & $\begin{array}{l}\text { AD 1447- } \\
1606\end{array}$ & $\begin{array}{l}\text { AD 1441- } \\
1618\end{array}$ & Rib & Male & $\begin{array}{l}\text { Young } \\
\text { Adult }\end{array}$ & $\overline{2}-\overline{6}$ & 11.0 & 9.6 & 3.2 \\
\hline $\begin{array}{l}\text { SK } \\
1151\end{array}$ & 15978 & $\begin{array}{l}\text { AD 1453- } \\
1617\end{array}$ & $\begin{array}{l}\text { AD 1446- } \\
1632\end{array}$ & M2 tooth & Male & $\begin{array}{l}\text { Young } \\
\text { Adult }\end{array}$ & $-\overline{-}$ & 10.9 & 3.7 & 3.3 \\
\hline $\begin{array}{l}\text { SK } \\
1224\end{array}$ & 11452 & $\begin{array}{l}\text { AD 881- } \\
971\end{array}$ & $\begin{array}{l}\text { AD 782- } \\
984\end{array}$ & Rib & Male & $\begin{array}{l}\text { Young } \\
\text { Adult }\end{array}$ & $\begin{array}{c}- \\
21.1\end{array}$ & 11.5 & 22.8 & 3.4 \\
\hline $\begin{array}{l}\text { SK } \\
1239 \mathrm{~B}\end{array}$ & 14984 & $\begin{array}{l}\text { AD 1174- } \\
1217\end{array}$ & $\begin{array}{l}\text { AD 1158- } \\
1252\end{array}$ & Rib & Male & $\begin{array}{l}\text { Young } \\
\text { Adult }\end{array}$ & $\begin{array}{c}- \\
21.6\end{array}$ & 11.1 & 4.9 & 3.2 \\
\hline SK 150 & 15971 & $\begin{array}{l}\text { AD 1425- } \\
1445\end{array}$ & $\begin{array}{l}\text { AD 1410- } \\
1455\end{array}$ & M2 tooth & Male & $\begin{array}{l}\text { Middle } \\
\text { Adult }\end{array}$ & $\begin{array}{c}- \\
21.1\end{array}$ & 10.8 & 8.4 & 3.2 \\
\hline SK 197 & 11442 & $\begin{array}{l}\text { AD 783- } \\
940\end{array}$ & $\begin{array}{l}\text { AD 779- } \\
965\end{array}$ & Rib & Male & $\begin{array}{l}\text { Middle } \\
\text { Adult }\end{array}$ & 20.9 & 10.1 & 15.7 & 3.5 \\
\hline SK 198 & 15972 & $\begin{array}{l}\text { AD 1286- } \\
1384\end{array}$ & $\begin{array}{l}\text { AD 1280- } \\
1389\end{array}$ & M2 tooth & Male & $\begin{array}{l}\text { Middle } \\
\text { Adult }\end{array}$ & 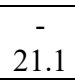 & 10.5 & 3.5 & 3.3 \\
\hline SK 530 & 11444 & $\begin{array}{l}\text { AD 1527- } \\
1654\end{array}$ & $\begin{array}{l}\text { AD 1519- } \\
1791\end{array}$ & Rib & Male & $\begin{array}{l}\text { Middle } \\
\text { Adult }\end{array}$ & 20.4 & 10.1 & 21.8 & 3.2 \\
\hline SK 542 & 14970 & $\begin{array}{l}\text { AD 1312- } \\
14\end{array}$ & $\begin{array}{l}\text { AD 1298- } \\
1412\end{array}$ & Rib & Male & $\begin{array}{l}\text { Middle } \\
\text { Adult }\end{array}$ & 20.8 & 10.6 & 2.3 & 3.3 \\
\hline SK 554 & 14980 & $\begin{array}{l}\text { AD 1217- } \\
1256\end{array}$ & $\begin{array}{l}\text { AD 1183- } \\
1268\end{array}$ & Vertebra & Male & $\begin{array}{l}\text { Middle } \\
\text { Adult }\end{array}$ & $\begin{array}{c}- \\
21.1\end{array}$ & 11.2 & 3.8 & 3.3 \\
\hline SK 809 & 14993 & $\begin{array}{l}\text { AD 1280- } \\
1378\end{array}$ & $\begin{array}{l}\text { AD 1275- } \\
1385\end{array}$ & Rib & Male & $\begin{array}{l}\text { Midde } \\
\text { Adult }\end{array}$ & - & 10.5 & 5.9 & 3.3 \\
\hline SK 885 & 11449 & $\begin{array}{l}\text { AD 781- } \\
936\end{array}$ & $\begin{array}{l}\text { AD 774- } \\
971\end{array}$ & Rib & Male & $\begin{array}{l}\text { Middle } \\
\text { Adult }\end{array}$ & $\begin{array}{c}- \\
21.3\end{array}$ & 11.8 & 21.0 & 3.6 \\
\hline $\begin{array}{l}\text { SK } \\
936 \mathrm{~A}\end{array}$ & 15980 & $\begin{array}{l}\text { AD 1447- } \\
1617\end{array}$ & $\begin{array}{l}\text { AD 1440- } \\
1633\end{array}$ & C tooth & Male & $\begin{array}{l}\text { Middle } \\
\text { Adult }\end{array}$ & 20.5 & 10.4 & 4.5 & 3.3 \\
\hline SK 984 & 11450 & $\begin{array}{l}\text { AD 1522- } \\
1645\end{array}$ & $\begin{array}{l}\text { AD 1495- } \\
1649\end{array}$ & Vertebra & Male & $\begin{array}{l}\text { Middle } \\
\text { Adult }\end{array}$ & $\overline{21.2}$ & 11.5 & 28.3 & 3.3 \\
\hline $\begin{array}{l}\text { SK } \\
1054\end{array}$ & 14991 & $\begin{array}{l}\text { AD 1266- } \\
1377\end{array}$ & $\begin{array}{l}\text { AD 1229- } \\
1388\end{array}$ & Rib & Male & $\begin{array}{l}\text { Middle } \\
\text { Adult }\end{array}$ & $\begin{array}{c}- \\
21.6\end{array}$ & 10.7 & 5.0 & 3.3 \\
\hline $\begin{array}{l}\text { SK } \\
1185\end{array}$ & 15979 & $\begin{array}{l}\text { AD 774- } \\
870\end{array}$ & $\begin{array}{l}\text { AD 694- } \\
889\end{array}$ & $\mathrm{C}$ tooth & Male & $\begin{array}{l}\text { Middle } \\
\text { Adult }\end{array}$ & $-\overline{2}$ & 11.8 & 4.8 & 3.2 \\
\hline $\begin{array}{l}\text { SK } \\
1225\end{array}$ & 15985 & $\begin{array}{l}\text { AD 1291- } \\
1385\end{array}$ & $\begin{array}{l}\text { AD 1284- } \\
1390\end{array}$ & Rib & Male & $\begin{array}{l}\text { Middle } \\
\text { Adult }\end{array}$ & $\overline{21.0}$ & 11.0 & 25.2 & 3.3 \\
\hline SK 84 & 14976 & $\begin{array}{l}\text { AD 1439- } \\
1457\end{array}$ & $\begin{array}{l}\text { AD 1432- } \\
1480\end{array}$ & Rib & Male & $\begin{array}{l}\text { Old } \\
\text { Adult }\end{array}$ & - & 10.8 & 5.3 & 3.3 \\
\hline $\begin{array}{l}\text { SK } \\
1030\end{array}$ & 14989 & $\begin{array}{l}\text { AD 1294- } \\
1386\end{array}$ & $\begin{array}{l}\text { AD 1287- } \\
1391\end{array}$ & Rib & Male & $\begin{array}{l}\text { Old } \\
\text { Adult }\end{array}$ & $\overline{-}$ & 10.2 & 13.8 & 3.3 \\
\hline SK 931 & 14986 & $\begin{array}{l}\text { AD 1524- } \\
1646\end{array}$ & $\begin{array}{l}\text { AD 1515- } \\
1661\end{array}$ & Rib & Male & Adult & $-\overline{-}$ & 10.7 & 5.6 & 3.3 \\
\hline $\begin{array}{l}\text { SK } \\
1038 \\
\end{array}$ & 14994 & $\begin{array}{l}\text { AD 1493- } \\
1630\end{array}$ & $\begin{array}{l}\text { AD 1474- } \\
1634\end{array}$ & Pelvis & Male & Adult & 20.5 & 10.4 & 7.6 & 3.3 \\
\hline & & & & & $\begin{array}{l}\text { Male } \\
\text { mean }\end{array}$ & & $2-$ & 10.7 & & \\
\hline
\end{tabular}


Table 2: Details of the juveniles from Ballyhanna included in the study.

\begin{tabular}{|c|c|c|c|c|c|c|c|c|c|c|}
\hline Context & $\begin{array}{l}\text { UB } \\
\text { Number } \\
\end{array}$ & $\begin{array}{l}\text { Calibrated } \\
\text { date }\end{array}$ & $\begin{array}{l}\text { Calibrated } \\
\text { date }\end{array}$ & $\begin{array}{l}\text { Skeletal } \\
\text { element }\end{array}$ & Sex & Age & $\delta^{13} \mathrm{C}$ & $\delta^{15} \mathbf{N}$ & Collagen & $\mathrm{C}: \mathrm{N}$ \\
\hline & & 1 sigma & 2 sigma & sampled & & & & & yield \% & \\
\hline SK 830 & 11459 & $\begin{array}{l}\text { AD 1451- } \\
1611\end{array}$ & $\begin{array}{l}\text { AD 1445- } \\
1620\end{array}$ & Rib & - & $\begin{array}{l}\text { Full term infant, } 41 \\
\text { weeks gestation }\end{array}$ & 20.8 & 11.8 & 4.9 & 3.3 \\
\hline SK 43 & 11456 & $\begin{array}{l}\text { AD 1451- } \\
1611\end{array}$ & $\begin{array}{l}\text { AD 1445- } \\
1620\end{array}$ & Rib & - & $\begin{array}{l}\text { Neonate, } 43 \text { weeks } \\
\text { gestation }\end{array}$ & $\begin{array}{c}- \\
19.1\end{array}$ & 14.7 & 5.0 & 3.3 \\
\hline $\begin{array}{l}\text { SK } \\
1100\end{array}$ & 11461 & $\begin{array}{l}\text { AD 1278- } \\
1292\end{array}$ & $\begin{array}{l}\text { AD 1271- } \\
1381\end{array}$ & Rib & - & Infant, $1-2$ months & 22.0 & 12.3 & 2.7 & 3.6 \\
\hline SK 455 & 14999 & $\begin{array}{l}\text { AD 1271- } \\
1283\end{array}$ & $\begin{array}{l}\text { AD 1263- } \\
1289\end{array}$ & Rib & - & $\begin{array}{l}\text { Younger Child, 1-3 } \\
\text { years }\end{array}$ & $\begin{array}{c}- \\
20.9\end{array}$ & 12.6 & 15.0 & 3.3 \\
\hline SK 858 & 15002 & $\begin{array}{l}\text { AD 1522- } \\
1650\end{array}$ & $\begin{array}{l}\text { AD 1494- } \\
1661\end{array}$ & Rib & - & $\begin{array}{l}\text { Younger child, 1-3 } \\
\text { years }\end{array}$ & $\begin{array}{c}- \\
20.5\end{array}$ & 13.2 & 4.1 & 3.3 \\
\hline SK 528 & 15000 & $\begin{array}{l}\text { AD 1219- } \\
1256\end{array}$ & $\begin{array}{l}\text { AD 1186- } \\
1270\end{array}$ & Rib & - & $\begin{array}{l}\text { Younger Child, 2-4 } \\
\text { years }\end{array}$ & $\begin{array}{c}- \\
20.8\end{array}$ & 11.0 & 3.8 & 3.3 \\
\hline $\begin{array}{l}\text { SK } \\
1029 \\
\end{array}$ & 11460 & $\begin{array}{l}\text { AD 1443- } \\
1469\end{array}$ & $\begin{array}{l}\text { AD 1435- } \\
1612\end{array}$ & Femur & - & $\begin{array}{l}\text { Younger Child, } 4.5- \\
6.5 \text { years }\end{array}$ & - & 11.2 & 17.5 & 3.3 \\
\hline SK 121 & 14997 & $\begin{array}{l}\text { AD 1443- } \\
1606 \\
\end{array}$ & $\begin{array}{l}\text { AD 1434- } \\
1619 \\
\end{array}$ & Rib & - & $\begin{array}{l}\text { Younger Child, 5-7 } \\
\text { years }\end{array}$ & $\begin{array}{c}- \\
20.6\end{array}$ & 11.1 & 3.2 & 3.3 \\
\hline SK 294 & 14998 & $\begin{array}{l}\text { AD 1288- } \\
1382\end{array}$ & $\begin{array}{l}\text { AD 1282- } \\
1388\end{array}$ & Femur & - & $\begin{array}{l}\text { Older child, } 5.5-7.5 \\
\text { years }\end{array}$ & $\begin{array}{c}- \\
20.7\end{array}$ & 10.2 & 6.1 & 3.3 \\
\hline SK 31 & 14996 & $\begin{array}{l}\text { AD 1466- } \\
1624\end{array}$ & $\begin{array}{l}\text { AD 1451- } \\
1634 \\
\end{array}$ & Rib & - & $\begin{array}{l}\text { Older Child, 6-8 } \\
\text { years }\end{array}$ & $\begin{array}{c}- \\
20.9\end{array}$ & 11.2 & 17.8 & 3.3 \\
\hline SK 541 & 15001 & $\begin{array}{l}\text { AD 1417- } \\
1433\end{array}$ & $\begin{array}{l}\text { AD 1410- } \\
1440\end{array}$ & Rib & - & $\begin{array}{l}\text { Older Child, 6-9 } \\
\text { years }\end{array}$ & $\begin{array}{c}- \\
21.2 \\
\end{array}$ & 10.5 & 18.3 & 3.3 \\
\hline SK 755 & 11458 & $\begin{array}{l}\text { AD 1440- } \\
1463\end{array}$ & $\begin{array}{l}\text { AD 1431- } \\
1607\end{array}$ & Rib & - & $\begin{array}{l}\text { Older Child, 7.5-9 } \\
\text { years }\end{array}$ & $\begin{array}{c}- \\
19.5\end{array}$ & 11.2 & 10.8 & 3.3 \\
\hline $\begin{array}{l}\text { SK } \\
1155\end{array}$ & 11463 & $\begin{array}{l}\text { AD 1289- } \\
1384\end{array}$ & $\begin{array}{l}\text { AD 1283- } \\
1389\end{array}$ & Femur & - & $\begin{array}{l}\text { Older Child, 8.5-10.5 } \\
\text { years }\end{array}$ & $\begin{array}{c}- \\
21.6\end{array}$ & 11.0 & 20.8 & 3.4 \\
\hline $\begin{array}{l}\text { SK } \\
1117\end{array}$ & 11462 & $\begin{array}{l}\text { AD 1453- } \\
1613\end{array}$ & $\begin{array}{l}\text { AD 1447- } \\
1620\end{array}$ & Rib & - & $\begin{array}{l}\text { Older Child, 9-12 } \\
\text { years }\end{array}$ & $\begin{array}{c}- \\
19.9\end{array}$ & 10.7 & 26.6 & 3.3 \\
\hline SK 355 & 11457 & $\begin{array}{l}\text { AD 1431- } \\
1446\end{array}$ & $\begin{array}{l}\text { AD 1419- } \\
1453\end{array}$ & Rib & - & $\begin{array}{l}\text { Adolescent, 12-14 } \\
\text { years }\end{array}$ & $\begin{array}{c}- \\
20.6\end{array}$ & 9.7 & 20.8 & 3.3 \\
\hline SK 1C & 11454 & $\begin{array}{l}\text { AD 1291- } \\
1386\end{array}$ & $\begin{array}{l}\text { AD 1284- } \\
1391\end{array}$ & Rib & Male & $\begin{array}{l}\text { Adolescent, 14-18 } \\
\text { years }\end{array}$ & - & 10.6 & 29.6 & 3.4 \\
\hline SK 861 & 15003 & $\begin{array}{l}\text { AD 1282- } \\
1383\end{array}$ & $\begin{array}{l}\text { AD 1276- } \\
1390\end{array}$ & Tibia & - & $\begin{array}{l}\text { Adolescent, 14-18 } \\
\text { years }\end{array}$ & $\begin{array}{c}- \\
20.9\end{array}$ & 10.0 & 2.3 & 3.3 \\
\hline SK 35 & 11455 & $\begin{array}{l}\text { AD 1270- } \\
1283\end{array}$ & $\begin{array}{l}\text { AD 1260- } \\
1291\end{array}$ & Rib & Male & $\begin{array}{l}\text { Adolescent, 15-18 } \\
\text { years }\end{array}$ & - & 9.5 & 22.4 & 3.3 \\
\hline
\end{tabular}


Table 3: Isotope values of the Ballyhanna faunal samples.

\begin{tabular}{|c|c|l|l|c|c|c|c|c|c|}
\hline SUBC No. & Cat. No. & \multicolumn{1}{|c|}{ Taxon } & Element & $\boldsymbol{\delta}^{\mathbf{1 3}} \mathbf{C}$ & $\boldsymbol{\delta}^{\mathbf{1 5}} \mathbf{N}$ & $\mathbf{\%} \mathbf{C}$ & $\mathbf{\% N}$ & $\mathbf{\%} \mathbf{C o l}$. & $\mathbf{C}: \mathbf{N}$ \\
\hline 11593 & 15005 & Cattle & Ulna & -22.6 & 6.4 & 40.6 & 14.3 & 12 & 3.3 \\
\hline 11594 & 15006 & Cattle & Scapula & -23.5 & 6.3 & 39.9 & 12.9 & 16 & 3.6 \\
\hline 11595 & 15007 & Cattle & Calcaneus & -22.9 & 6.0 & 41.0 & 13.7 & 17 & 3.5 \\
\hline 11596 & 15008 & Cattle & Calcaneus & -21.9 & 5.1 & 40.7 & 14.3 & 27 & 3.3 \\
\hline 11597 & 15009 & Cattle & Calcaneus & -23.3 & 6.7 & 39.0 & 13.5 & 12 & 3.4 \\
\hline 11598 & 15010 & Cattle & Calcaneus & -22.7 & 7.0 & 40.4 & 14.0 & 24 & 3.4 \\
\hline 11599 & 15011 & Horse & Phalanx 3 & -22.8 & 5.3 & 40.6 & 14.4 & 22 & 3.3 \\
\hline 11601 & 15013 & Sheep/goat & Humerus & -22.1 & 7.8 & 40.3 & 14.2 & 15 & 3.3 \\
\hline 11602 & 15014 & Sheep/goat & Humerus & -22.2 & 6.1 & 40.2 & 14.3 & 20 & 3.3 \\
\hline 11603 & 15015 & Sheep/goat & Humerus & -23.0 & 6.2 & 39.8 & 13.3 & 14 & 3.5 \\
\hline & & $\begin{array}{l}\text { Herbivore } \\
\text { mean }\end{array}$ & & $-\mathbf{2 2 . 7}$ & $\mathbf{6 . 3}$ & $\begin{array}{c}\mathbf{( n = 1 0} \text { excluding } \\
\text { pig) }\end{array}$ & & & \\
\hline 11600 & 15012 & Pig & Ulna & -22.0 & 7.2 & 40.6 & 14.3 & 25 & 3.3 \\
\hline
\end{tabular}

\section{References}

Ambrose, S.H. 1990. Preparation and characterization of bone and tooth collagen for isotopic analysis. Journal of Archaeological Science 17, 431-451.

Ambrose, S.H. and Norr, L. 1993. Experimental evidence for the relationship of the carbon isotope ratios of whole diet and dietary protein to those of bone collagen and carbonate, pp.137 in Lambert, J.B. and Grupe, G. (eds), Prehistoric Human Bone. Springer: Berlin. Barry, J. and Morgan, H. 2013. Great Deeds in Ireland: Richard Stanihurst's De Rebus in Hibernia Gestis. Cork University Press: Cork.

Beaumont, J. Geber, J. Powers, N. Wilson, A. Lee-Thorp, J. and Montgomery, J. 2013. Victims and survivors: stable isotopes used to identify migrants from the Great Irish Famine to 19th century London. American Journal of Physical Anthropology 150, 87-98.

Beaumont, J., Atkins, E.-C., Buckberry, J., Haydock, H., Horne, P., Howcroft, R., Mackenzie, K. and Montgomery, J. 2018. Comparing apples and oranges: Why infant bone collagen may not reflect dietary intake in the same way as dentine collagen. American Journal of Physical Anthropology 167, 524-540. 
Beglane, F. 2012. Animal bone, pp. 109-120 in Foley, C. and Donnelly, C. (eds) Parke's Castle, Co. Leitrim: Archaeology, History and Architecture (Archaeological Monograph Series 7), The Stationery Office: Dublin.

Beglane, F. In press. The fat of the land: meat and milk products in medieval Ireland, in Atici, L. and Arbuckle, B. (eds), Food Provisioning in Complex Societies. University Press of Colorado: Colorado.

Bocherens, H. and Drucker, D. 2003. Trophic level isotopic enrichment of carbon and nitrogen in bone collagen: case studies from recent and ancient terrestrial ecosystems. International Journal of Osteoarchaeology 13, 46-53.

Bronk Ramsey, C., Higham, T., Bowles, A., Hedges, R. 2004. Improvements to the Pretreatment of Bone at Oxford. Radiocarbon. 46, 155-163.

Brookes, S.T. and Belanger, C. 2005. IA-R041 $-{ }^{15} \mathrm{~N} /{ }^{13} \mathrm{C}$ L-Alanine Laboratory Standard, Report of Analysis, Iso-Analytical Limited, Sandbach, Cheshire, UK.

Brooks, S.T. and Suchey, J.M. 1990. Skeletal age determination based on the os pubis: a comparison of the Acsádi-Nemeskéri and Suchey-Brooks methods. Human Evolution 5, 227238.

Brothwell, D.R. 1981. Digging up Bones. Cornell University Press: New York.

Brown, T.A., Nelson, D.E., Vogel, J.S. and Southon, J.R. 1988. Improved collagen extraction by modified Longin method. Radiocarbon 30, 171-177.

Buckley, L., Ní Mhurchú, C., Matthews, A., Park, V., Carty, N., Rouard, O., Swift, L. and Foster, H. 2010. Skeletal Report, A1/N1 Newry-Dundalk Link Road, Site 116, Faughart Lower, Co. Louth. Unpublished report prepared for Archaeological Development Services.

Chisholm, B.S., Nelson, D.E., and Schwarcz, H.P. 1982. Stable-carbon isotope ratios as a measure of marine versus terrestrial protein in ancient diets. Science 216, 1131-1132. 
Collins, M, and Galley, P. 1998. Towards an optimal method of archaeological collagen extraction: the influence of $\mathrm{pH}$ and grinding. Ancient Biomolecules 2, 209-223.

Collins, R.P. and Jones, M.B. 1986. The influence of climatic factors on the distribution of C4 species in Europe. Vegetatio 64, 121-129.

Coplen, T.B., Brand, W.A., Gehre, M., Gröning, M., Meijer, H.A.J., Toman, B., Verkouteren, R.M. 2006. New guidelines for $\delta 13 C$ measurements. Analytical Chemistry 78, 2439-2441.

Cunningham, C., Scheuer, L. and Black, S. 2016. Developmental Juvenile Osteology (second edition). Elsevier Academic Press: London.

DeNiro, M.J. 1985. Postmortem preservation and alteration of in vivo bone collagen isotope ratios in relation to palaeodietary reconstruction. Nature $317,806-809$.

DeNiro, M.J. and Epstein, S. 1978. Influence of diet on the distribution of carbon isotopes in animals. Geochimica et Cosmochimica Acta 42, 495-506.

DeNiro, M.J. and Epstein, S. 1981. Influence of diet on the distribution of nitrogen isotopes in animals. Geochimica et Cosmochimica Acta 45, 341-351.

Dodds, M.L. 1960. The cariogenic property of cereal foods. Journal of Nutrition 71, 317-321.

Donnelly, C.J. 2015. Ballyshannon and Ballyhanna during the medieval period, pp. 15-46 in McKenzie, C.J., Murphy, E.M. and Donnelly, C.J. (eds), The Science of a Lost Medieval Gaelic Graveyard: The Ballyhanna Research Project. Transport Infrastructure Ireland: Dublin.

Farrell, G. 2017. The 'Mere Irish' and the Colonisation of Ulster, 1570-1641. Palgrave Macmillan: Switzerland.

Ferembach, D., Schwidetzky, I. and Stloukal, M. 1980. Recommendations for age and sex diagnoses of skeletons. Journal of Human Evolution 9, 517-549. 
Geber, J. 2010. Appendix 6 Osteological Report, pp. 131-348 in Lehane, J. and Delaney, F. (eds), Archaeological Excavation Report E3770 - Owenbristy, Co. Galway: Cashel and Burial Ground. Eachtra Journal 8, 1-385.

Geber, J. 2011. Human remains from Owenbristy, pp.88-97 in Delaney, F. and Tierney, J. (eds) In the Lowlands of South Galway: Archaeological Excavations on the N18 Oranmore to Gort National Road Scheme. The National Roads Authority Scheme Monograph 7. The National Roads Authority: Dublin.

Guiry, E.J. 2019. Complexities of stable carbon and nitrogen isotope biogeochemistry in ancient freshwater ecosystems: implications for the study of past subsistence and environmental change. Frontiers of Ecology and Evolution. doi: 10.3389/fevo.2019.00313

Guiry, E.J. and Hunt, B.P. 2020. Integrating fish scale and bone isotopic compositions for 'deep time' retrospective studies. Marine Environmental Research 160, 104982.

Guiry, E.J., Szpak, P. and Richards, M.P. 2016b. Effects of lipid extraction and ultrafiltration on stable carbon and nitrogen isotopic compositions of fish bone collagen. Rapid Communications in Mass Spectrometry 30, 1591-1600.

Guiry, E.J., Szpak, P. and Richards, M.P. 2017. Isotopic analyses reveal geographical and socioeconomic patterns in historical animal trade between predominantly wheat- and maizegrowing agricultural regions in eastern North America. American Antiquity 82, 341-352.

Guiry, E.J. Harpley, B., Jones, Z., Smith, C. 2014. Integrating stable isotope and zooarchaeological analyses in historical archaeology: a case study from the urban nineteenthcentury Commonwealth Block site, Melbourne, Australia. International Journal of Historical Archaeology 18, 415-440.

Guiry, E.J., Noël, S., Tourigny, E. and Grimes, V. 2012. A stable isotope method for identifying transatlantic origin of pig (Sus scrofa) remains at French and English fishing stations in Newfoundland. Journal of Archaeological Science 39, 2012-2022. 
Guiry, E., Beglane, F., Szpak, P., Schulting, R., McCormick, F., Richards, M.P. 2018a. Anthropogenic changes to the Holocene nitrogen cycle in Ireland. Science Advances 4, eaas 9383.

Guiry, E.J., Jones, B.M., deFrance, S., Bruseth, J.E., Durst, J. and Richards, M.P. 2018b. Animal husbandry and colonial adaptive behaviour: Isotopic insights from the La Belle Shipwreak Fauna. Historical Archaeology 52, 684-699.

Guiry, E.J., Staniforth, M., Nehlich, O., Grimes, V., Smith, C., Harpley, B., Noël, S. and Richards, M.P. 2015. Tracing historical animal husbandry, meat trade, and food provisioning: A multi-isotopic approach to the analysis of shipwreak faunal remains from the William Salthouse, Port Philip, Australia. Journal of Archaeological Science Reports 1, 21-28.

Guiry, E.J. Needs-Howarth, S., Friedland, K.D., Hawkins, A.L., Szpak, P., Macdonald, R., Courtemanche, M., Holm, E. and Richards, M.P. 2016a. Lake Ontario salmon (Salmo salar) were not migratory: a long-standing historical debate solved through stable isotope analysis. Scientific Reports 6: 36249.

Hammer, Ø, Harper, D.A., Ryan, P.D. 2001. PAST: paleontological statistics software package for education and data analysis, Palaeontologia Electronica 4, 9.

Hamilton-Dyer, S. 2012. Bird and fish bone, pp. 120 in Foley, C. and Donnelly, C. (eds) Parke's Castle, Co. Leitrim: Archaeology, History and Architecture (Archaeological Monograph Series 7). The Stationery Office: Dublin.

Harrod, C., Grey, J., McCarthy, T.K. and Morrissey, M. 2005. Stable isotope analyses provide new insights into ecological plasticity in a mixohaline population of European eel. Oecologia 144, 673-683.

Hatchell, G. 1966. Irish Patent Rolls of James I: Facsimile of the Irish Record Commission's Calendar, Prepared Prior to 1830. Dublin: Stationery Office for the Irish Manuscripts Commission (foreword by M.C. Griffith). 
Hedges, R.E. and Reynard, L.M. 2007. Nitrogen isotopes and the tropic level of humans in archaeology. Journal of Archaeological Science 34, 1240-1251.

Hillson, S. 1996. Dental Anthropology. Cambridge University Press: Cambridge.

Hillson, S. 2008. The current state of dental decay, pp. 111-135 in Irish, J.D. and Nelson, G.C. (eds), Technique and Application in Dental Anthropology. Cambridge University Press: Cambridge.

Hobson, K.A., Alisauskas, R.T. and Clark, R.G. 1993. Stable-nitrogen isotope enrichment in avian tissues due to fasting and nutritional stress: Implications for isotopic analyses of diet. The Condor 95, 388-394.

Hutchinson, W.F., Culling, M., Orton, D.C., Hänfling, B., Lawson Handley, L., HamiltonDyer, S., O’Connell, T.C., Richards, M.P. and Barrett, J.H. 2015. The globalization of naval provisioning: ancient DNA and stable isotope analyses of stored cod from the wreck of the Mary Rose, AD 1545. Royal Society Open Science 2:150199.

Jennings, S. and van der Molen, J. 2015. Trophic levels of marine consumers from nitrogen stable isotope analysis: estimation and uncertainty. ICES Journal of Marine Science: Journal du Conseil 72, 2289-2300.

Katzenberg, M.A. 1989. Stable isotope analysis of archaeological faunal remains from Southern Ontario. Journal of Archaeological Science 16, 319-329.

Keenleyside, A. 2008. Dental pathology and diet at Apollonia, a Greek colony on the Black Sea. International Journal of Osteoarchaeology 18, 262-279.

Kelly, F. 1997. Early Irish Farming: A Study Based Mainly on the Law Texts of the 7th and 8th centuries $A D$. Dublin Institute for Advanced Studies: Dublin.

Knudson, K.J., O’Donnabhain, B., Carver, C., Cleland, R. and Price, T.D. 2012. Migration and Viking Dublin: paleomobility and paleodiet through isotopic analyses. Journal of Archaeological Science 39, 308-320. 
Larsen, C.S. 2015. Bioarchaeology: Interpreting behaviour from the human skeleton (second edition). Cambridge University Press: Cambridge.

Lee-Thorp, J.A. 2008. On isotopes and old bones. Archaeometry 50, 925-950.

Levene, H. 1960. Robust test for equality of variances, pp.278-292 in Olkin, I., Ghurye, S.G., Hoeffding, W., Madow, W.G. and Mann, H.B. (eds), Contributions to probability and statistics: Essays in honor of Harold Hotelling. Stanford University Press: Palo Alto, CA.

Longin, R. 1971. New method of collagen extraction for radiocarbon dating. Nature 230, 241.

Lovejoy, C.O., Meindl, R.S., Pryzbeck, T.R. and Mensforth, R.P.1985. Chronological metamorphosis of the auricular surface of the ilium: A new method for the determination of adult skeletal age at death. American Journal of Physical Anthropology 68, 15-28.

Lukacs, J.R. 1989. Dental palaeopathology: Methods for reconstructing dietary patterns, pp. 261-286 in Işcan, M.Y. and Kennedy, K.A.R. (eds), Reconstruction of Life from the Skeleton. Alan Liss Inc: New York.

Lukacs, J.R. 2012. Oral Health in Past Populations: Context, concepts and controversies, pp. 554-581 in Grauer, A.L. (ed.) A Companion to Paleopathology. Wiley-Blackwell: New York.

Lukacs, J.R. and Largaespada, L.L. 2006. Explaining sex differences in dental caries prevalence: Saliva, hormones, and 'life-history' etiologies. American Journal of Human Biology 18, 540-555

Macdonald, P. and Carver, N. 2015. Archaeological excavations at Ballyhanna graveyard chronology, development and context, pp. 47-84 in McKenzie, C.J., Murphy, E.M. and Donnelly, C.J. (eds), The Science of a Lost Medieval Gaelic Graveyard: The Ballyhanna Research Project. Transport Infrastructure Ireland: Dublin. 
Mac Eiteagáin, D. 1995. The renaissance and the late medieval lordship of Tír Chonaill 14611555, pp. 203-228 in Nolan, W., Ronayne, L. and Dunlevy, M. (eds), Donegal History and Society. Geography Publications: Dublin.

Maloy, A.P., Nelle, P. Culloty, S.C. Slater, J.W. and Harrod, C. 2013. Identifying trophic variation in a marine suspension feeder: DNA- and stable isotope-based dietary analysis in Mytilus spp. Marine Biology 160, 479-490.

Mann, H.B. and Whitney, D.R. 1947. On a test of whether one or two random variables is stochastically larger than the other. The Annals of Mathematical Statistics 18, 50-60.

McCormick, F. and Murray, E. 2007. Knowth and the Zooarchaeology of Early Christian Ireland. Royal Irish Academy: Dublin.

McCormick, F., Gibbon, M., McCormac, F.G. and Moore, J. 1996. Bronze Age to Medieval Coastal Shell Middens Near Ballyconneelly, Co. Galway. The Journal of Irish Archaeology 7, 77-84.

McKenzie, C.J. and Murphy, E.M. 2018. Life and Death in Medieval Gaelic Ireland: The Skeletons from Ballyhanna, Co. Donegal. Four Courts Press: Dublin.

Milner, N. and Woodman, P. 2007. Deconstructing the myths of Irish shell middens, pp. 101110 in Milner, N., Craig, O.E. and Bailey, G.N (eds), Shell middens in Atlantic Europe. Oxbow Books: Oxford.

Mitchell, P.D. and Brickley, M. (eds) 2017. Updated Guidelines to the Standards for Recording Human Remains (Chartered Institute for Archaeologists/ British Association for Biological Anthropology and Osteoarchaeology). CIfA and BABAO: Reading.

Moorrees, C.F.A, Fanning, E.A. and Hunt, E.E. 1963. Formation and resorption of three deciduous teeth in children. American Journal of Physical Anthropology 21, 205-13. 
Murphy, E.M. 2004. The animal bone, pp. 97-101 in Anderson, S. and Rees, A. The excavation of a medieval rural settlement site at Portmuck, Islandmagee, County Antrim. Ulster Journal of Archaeology 63, 76-113.

Murphy, E.M. 2007. An overview of livestock husbandry and economic practices in the urban environments of post-medieval Ireland, pp. 371-392 in Horning, A., Ó Baoill, R., Donnelly, C. and Logue, P. (eds), The Post-Medieval Archaeology of Ireland 1550-1850. Wordwell Ltd: Dublin.

Murphy, M. and Potterton, M. 2010. The Dublin Region in the Middle Ages: Settlement, Land-use and Economy. Four Courts Press: Dublin.

Murray, E. 2007. Molluscs and middens: the archaeology of "Ireland's early savage race"?, pp. 119-135 in Murphy, E.M and Whitehouse, N.J. (eds), Environmental Archaeology in Ireland. Oxford Books: Oxford.

Nicholls, K.W. 2003. Gaelic and Gaelicized Ireland in the Middle Ages. Lilliput Press: Dublin.

Novak, M. 2015. Dental health and diet in early medieval Ireland. Archives of Oral Biology 60, 1299-1309.

O’Connell, T.C., Kneale, C.J., Tasevska, N. and Kuhnle, G.G. 2012. The diet-body offset in human nitrogen isotopic values: A controlled dietary study. American Journal of Physical Anthropology 149, 426-434.

O’Connor, T. 2000. The Archaeology of Animal Bones. Sutton Publishing Ltd: Stroud.

Ó Doibhlin, E. 1998. O Neill's “Own Country” and its Families. Donaghmore Historical Society: Donaghmore.

O’Dowd, M. 1986. Gaelic economy and society, pp. 120-47 in Brady, C. and Gillespie, R. (eds), Natives and Newcomers: Essays on the Making of Irish Colonial Society, 1534-1641. Irish Academic Press: Dublin. 
Pearson, K. 1900. On the criterion that a given system of deviations from the probable in the case of a correlated system of variables is such that it can be reasonably supposed to have arisen from random sampling. Philosophical Magazine. Series 5, 50 (302): 157-175.

Phenice, T.W. 1969. A newly developed visual method of sexing the os pubis. American Journal of Physical Anthropology 30, 297-301.

Post, D.M. 2002. Using stable isotopes to estimate trophic position: models, methods, and assumptions. Ecology 83, 703-718.

Power, C. 1995. A medieval demographic sample, pp. 66-83 in Hurley, M.F. and Sheehan, C.M. (eds), Excavations at the Dominican Priory St Mary's of the Isle, Cork. Cork Corporation: Cork.

Qi, H., Coplen, T.B., Geilmann, H., Brand, W.A., Böhlke, J.K. 2003. Two new organic reference materials for $\delta^{13} \mathrm{C}$ and $\delta^{15} \mathrm{~N}$ measurements and a new value for the $\delta^{13} \mathrm{C}$ of NBS 22 oil. Rapid Communications in Mass Spectrometry 30, 2483-7.

Randolph-Quinney, P. 2009. 8.1 Human remains, pp. 1-138 in Channing, J. (ed.), N6 Kilbeggan to Kinnegad Dual Carriageway: Archaeological Resolution. Final Report, Ballykilmore 6, Co. Westmeath (Volume 2). Unpublished report prepared for Valerie J. Keeley Ltd.

Reimer, P.J., Baillie, M.G.L., Bard, E., Bayliss, A., Beck, J.W., Blackwell, P.G., Bronk Ramsey, C., Buck, C.E., Burr, G.S., Edwards, R.L., Friedrich, M., Grootes, P.M., Guilderson, T.P., Hajdas, I., Heaton, T.J., Hogg, A.G., Hughen, K.A., Kaiser, K.F., Kromer, B., McCormac, F.G., Manning, S.W., Reimer, R.W., Richards, D.A., Southon, J.R., Talamo, S., Turney, C.S.M., van der Plicht, J. and Weyhenmeyer, C.E. 2009. IntCa109 and Marine09 radiocarbon age calibration curves, 0-50,000 years cal BP. Radiocarbon 51, 1111-1150.

Reitsema, L.J., Brown, T.E., Hadden, C.S., Cutts, R.B., Little, M.E., Richison, B.T. 2015. Provisioning an urban economy: Isotopic perspectives on landscape use and animal sourcing on the Atlantic coastal plain. Southeastern Archaeology 34, 237-254. 
Ryan, S.E., Reynard, L.M., Crowley, Q.G., Snoeck, C. and Tuross, N. 2018. Early medieval reliance on the land and the local: An integrated mutli-isotope study $(87 \mathrm{Sr} / 86 \mathrm{Sr}, \delta 18 \mathrm{O}, \delta 13 \mathrm{C}, \delta 15 \mathrm{~N})$ of diet and migration in Co. Meath, Ireland. Journal of Archaeological Science 98, 59-71.

Scheuer, L. and Black, S. 2000. Developmental Juvenile Osteology. Elsevier Academic Press: London.

Schoeninger, M.J., DeNiro, M.J. and Tauber, H. 1983. Stable nitrogen isotope ratios of bone collagen reflect marine and terrestrial components of prehistoric human diet. Science 220, $1381-1383$.

Shapiro, S. and Wilk, M. 1965. An analysis of variance test for normality. Biometrika 52, 591-611.

Smith, B.H. 1991. Standards of human tooth formation and dental age assessment, pp. 143168 in Kelley, M.A. and Larsen, C.S. (eds), Advances in Dental Anthropology. Wiley-Liss Inc: New York.

Spearman, C. 1907. Demonstration of formulae for true measurement of correlation. The American Journal of Psychology 18, 161-169.

Student. 1908. The probable error of a mean. Biometrika 6, 1-25.

Szpak, P. 2014. Complexities of nitrogen isotope biogeochemistry in plant-soil systems: implications for the study of ancient agricultural and animal management practices. Frontiers in Plant Science 5, 1-19.

Szpak, P. Krippner, K., Richards, M.P. 2017a. Effects of sodium hydroxide treatment and ultrafiltration on the removal of humic contaminants from archaeological bone. International Journal of Osteoarchaeology 27, 1070-1077. 
Szpak, P. Metcalfe, J.Z. Macdonald, R.A. 2017b. Best practice for calibrating and reporting stable isotope measurements in archaeology. Journal of Archaeological Science: Reports 13, 609-616.

Szpak, P., Orchard, T.J., McKechnie, I. and Gröcke, D.R. 2012. Historical ecology of late Holocene sea otters (Enhydra lutris) from northern British Columbia: isotopic and zooarchaeological perspectives. Journal of Archaeological Science 39, 1553-1571.

Tieszen, L.L. 1991. Natural variations in the carbon isotope values of plants: implications for archaeology, ecology and paleoecology. Journal of Archaeological Science 18, 227-248.

Troy, C. 2010. Final Report on the Human Remains from Ardreigh, Co. Kildare (Volume 1: Report). Unpublished report prepared for Headland Archaeology Ltd.

Tukey, J.W. 1949. Comparing individual means in the analysis of variance. Biometrics 5, 99114.

Van Klinken, G.J., Richards, M.P. and Hedges, R.E.M. 2002. An overview of causes for stable isotopic variations in past European human populations: environmental, ecophysiological, and cultural effects, pp. 39-63 in Ambrose, S.H. and Katzenberg, M.A. (eds), Biogeochemical Approaches to Paleodietary Analysis. Springer US: Boston.

Vogel, J.C. and van der Merwe, N.J. 1977. Isotopic evidence for early maize cultivation in New York State, American Antiquity 42, 238-242.

Welch, B.L. 1947. The generalization of 'Student's' problem when several different population variances are involved. Biometrika 34, 28-35.

Went, A.E.J. 1961. Historical notes on the oyster fisheries of Ireland. Proceedings of the Royal Irish Academy: Archaeology, Culture, History, Literature 62, 195-223. 